\title{
Natural Antioxidants in Foods and Medicinal Plants: Extraction, Assessment and Resources
}

\author{
Dong-Ping Xu ${ }^{1}$, Ya Li ${ }^{1}$, Xiao Meng ${ }^{1}$, Tong Zhou ${ }^{1}$, Yue Zhou ${ }^{1}$, Jie Zheng ${ }^{1}$, Jiao-Jiao Zhang ${ }^{1}$ \\ and Hua-Bin $\mathrm{Li}^{1,2, *}$ \\ 1 Guangdong Provincial Key Laboratory of Food, Nutrition and Health, School of Public Health, Sun Yat-Sen \\ University, Guangzhou 510080, China; xudp@mail2.sysu.edu.cn (D.-P.X.); liya28@mail2.sysu.edu.cn (Y.L.); \\ mengx7@mail2.sysu.edu.cn (X.M.); zhout43@mail2.sysu.edu.cn (T.Z.); zhouyue3@mail2.sysu.edu.cn (Y.Z.); \\ zhengj37@mail2.sysu.edu.cn (J.Z.); zhangjj46@mail2.sysu.edu.cn (J.-J.Z.) \\ 2 South China Sea Bioresource Exploitation and Utilization Collaborative Innovation Center, \\ Sun Yat-Sen University, Guangzhou 510006, China \\ * Correspondence: lihuabin@mail.sysu.edu.cn; Tel.: +86-20-8733-2391
}

Academic Editors: David Arráez-Román and Ana Maria Gómez Caravaca Received: 21 October 2016; Accepted: 27 December 2016; Published: 5 January 2017

\begin{abstract}
Natural antioxidants are widely distributed in food and medicinal plants. These natural antioxidants, especially polyphenols and carotenoids, exhibit a wide range of biological effects, including anti-inflammatory, anti-aging, anti-atherosclerosis and anticancer. The effective extraction and proper assessment of antioxidants from food and medicinal plants are crucial to explore the potential antioxidant sources and promote the application in functional foods, pharmaceuticals and food additives. The present paper provides comprehensive information on the green extraction technologies of natural antioxidants, assessment of antioxidant activity at chemical and cellular based levels and their main resources from food and medicinal plants.
\end{abstract}

Keywords: antioxidant; extraction; assessment; resource

\section{Introduction}

In biological system, reactive oxygen species (ROS) and reactive nitrogen species (RNS), such as superoxide, hydroxyl, and nitric oxide radicals, can damage the DNA and lead to the oxidation of lipid and proteins in cells [1-3]. Normally, antioxidant system occurring in human body can scavenge these radicals, which would keep the balance between oxidation and anti-oxidation. Nonetheless, the exposure of cigarette smoking, alcohol, radiation, or environmental toxins induces the production of excessive ROS and RNS, which disrupt the balance between oxidation and anti-oxidation and result in some chronic and degenerative diseases [3-5]. The increment of intake of exogenous antioxidants would ameliorate the damage caused by oxidative stress through inhibiting the initiation or propagation of oxidative chain reaction, acting as free radical scavengers, quenchers of singlet oxygen and reducing agents [6].

The exogenous antioxidants are mainly derived from food and medicinal plants, such as fruits, vegetables, cereals, mushrooms, beverages, flowers, spices and traditional medicinal herbs [7-18]. Besides, the industries processing agricultural by-products are also potentially important sources of natural antioxidants [19]. These natural antioxidants from plant materials are mainly polyphenols (phenolic acids, flavonoids, anthocyanins, lignans and stilbenes), carotenoids (xanthophylls and carotenes) and vitamins (vitamin E and C) [6,20]. Generally, these natural antioxidants, especially polyphenols and carotenoids, exhibit a wide range of biological effects, such as anti-inflammatory, antibacterial, antiviral, anti-aging, and anticancer [2,20-31].

Considering their important health effects, the efficient extraction methods of natural antioxidants, appropriate assessment of antioxidant activity as well as their main resources from food and medicinal 
plants are drawing great attention in food science and nutrition. To improve the extraction efficiency of antioxidant components from plant materials, several green non-conventional methods have been developed for reducing operational time and usage of organic solvents, such as ultrasound-assisted extraction, microwave-assisted extraction, enzyme-assisted extraction, pressurized liquid extraction, supercritical fluid extraction, high hydrostatic pressure extraction, pulsed electric field extraction and high voltage electrical discharges extraction. Moreover, to further assess the antioxidant capacities of extracts from natural products, especially those frequently consumed by people, different evaluation assays have been developed, e.g., Trolox equivalence antioxidant capacity (TEAC) assay, ferric ion reducing antioxidant power (FRAP) assay, oxygen radical absorbance capacity (ORAC) assay, inhibiting the oxidation of low-density lipoprotein (LDL) assay, cellular antioxidant activity assay, etc. These assays have been used for ranking the antioxidant plants and recommending best antioxidant foods for consumption. This review is aimed at summarizing the extraction methods of natural antioxidants, assessment methods of antioxidant activity and their main resources from food and medicinal plants.

\section{Extraction Methods of Antioxidants from Foods and Medicinal Plants}

Extraction is the first and crucial step for studying the natural antioxidants from plants (Figure 1). Many extraction factors play important roles in the extraction efficiency, such as type and concentration of extraction solvent, extraction temperature, extraction time, and extraction $\mathrm{pH}$. Among them, the solvent is one of the most influential factors. Numerous solvents have been used for the extraction of antioxidants from food and medicinal plants. The selection of solvents is based on the chemical nature and polarity of antioxidant compounds to be extracted. Most of the phenolics, flavanoids and anthocyanins are hydrosoluble antioxidants. The polar and medium polar solvents, such as water, ethanol, methanol, propanol, acetone and their aqueous mixtures, are widely used for extraction [32-35]. Carotenoids are lipid-soluble antioxidants, and common organic solvents, such as the mixtures of hexane with acetone, ethanol, methanol, or mixtures of ethyl acetate with acetone, ethanol, methanol, have been used for extraction [36-38].

Various extraction procedures, including conventional extraction methods and non-conventional extraction methods, can be chosen to extract antioxidants from food and medicinal plants. The conventional extraction methods are mainly hot water bath, maceration and Soxhlet extraction, which are very time-consuming and require relatively large amounts of organic solvents with low extraction yields [39-41]. Furthermore, the long heating process such as hot water bath and Soxhlet extraction may lead to the degradation of the thermolabile compounds. To obtain antioxidants from plants in an energy-efficient and economically sustainable way, ultrasound, microwave, pressurized liquid, enzyme hydrolysis, supercritical fluids, high hydrostatic pressure, pulsed electric field, and high voltage electrical discharges have been studied as non-conventional methods (Table 1). In this section, the current application and developments of the non-conventional methods are summarized. 


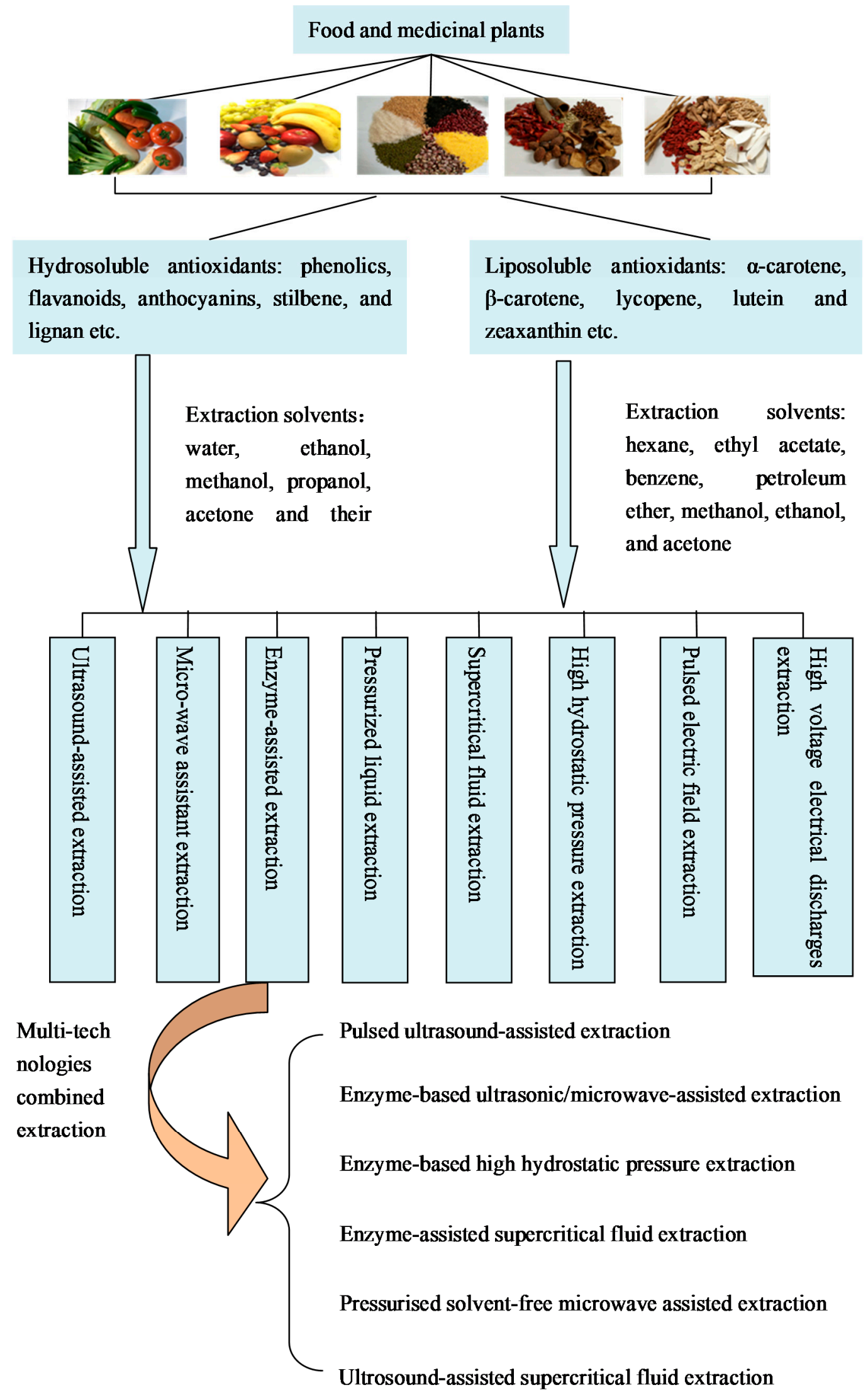

Figure 1. The outline of extraction of antioxidants from foods and medicinal plants. 
Table 1. The application of non-conventional techniques in the extraction of antioxidants from some foods and medicinal plants.

\begin{tabular}{|c|c|c|c|c|c|}
\hline \multirow{2}{*}{ Source } & \multirow{2}{*}{ Compounds Extracted } & \multicolumn{2}{|c|}{ Extraction Parameters } & \multirow{2}{*}{ Extraction Improvement } & \multirow{2}{*}{ Reference } \\
\hline & & Non-Conventional Method & Conventional Methods & & \\
\hline \multicolumn{6}{|c|}{ ultrasound-assisted extraction (UAE) } \\
\hline blueberry wine pomace & anthocyanins and phenolics & $\begin{array}{l}\text { solvents: } 70 \% \text { ethanol and } 0.01 \% \\
\text { hydrochloric acid; conditions: } \\
400 \mathrm{w}, 61.03^{\circ} \mathrm{C}, 23.67 \mathrm{~min}\end{array}$ & $\begin{array}{l}70 \% \text { ethanol and } 0.01 \% \text { hydrochloric } \\
\text { acid; } 61^{\circ}{ }^{\circ} \mathrm{C}, 35 \text { min without } \\
\text { ultrasound treatment }\end{array}$ & $\begin{array}{l}\text { increased total anthocyanins from } 1.72 \text { to } \\
4.27 \mathrm{mg} \mathrm{C}_{3} \mathrm{G} / \mathrm{g} \text { ( } 2.5 \text {-fold) and total } \\
\text { phenolics from } 5.08 \text { to } 16.41 \mathrm{mg} \text { gallic } \\
\text { acid equivalent (GAE)/g (about } 3.2 \text {-fold) }\end{array}$ & [42] \\
\hline papaya & lycopene & $\begin{array}{l}\text { solvents: } 42.28 \% \text { ethanol in ethyl } \\
\text { acetate conditions: } 40 \mathrm{kHz}, 800 \mathrm{~W} \text {, } \\
26.09 \mathrm{~min}, 50.12{ }^{\circ} \mathrm{C}\end{array}$ & $\begin{array}{l}40 \% \text { ethanol in ethyl acetate }(300 \mathrm{~mL}) \\
95^{\circ} \mathrm{C} \text { in a Soxhlet extractor }\end{array}$ & $\begin{array}{l}\text { Recovery of lycopene increased } \\
\text { from } 68.3 \pm 4.1 \text { to } 189.8 \pm 4.5 \mu \mathrm{g} / \mathrm{g}\end{array}$ & [43] \\
\hline carrot & carotenoids & $\begin{array}{l}\text { solvents: sunflower oil conditions: } \\
22.5 \mathrm{~W} / \mathrm{cm}^{2}, 40^{\circ} \mathrm{C}, 20 \mathrm{~min}\end{array}$ & $\begin{array}{l}\text { hexane at room temperature } \\
\text { for one hour }\end{array}$ & $\begin{array}{l}\text { obtained the } \beta \text {-carotene yield } \\
\text { of } 334.75 \mathrm{mg} / \mathrm{L} \text { just in } 20 \mathrm{~min} \text { while the } \\
\text { CSE method using hexane as solvent } \\
\text { obtained the } \beta \text {-carotene yield } \\
\text { of } 321.36 \mathrm{mg} / \mathrm{L} \text { after one-hour extraction }\end{array}$ & [44] \\
\hline \multicolumn{6}{|c|}{ microwave-assisted extraction (MAE) } \\
\hline Achillea millefolium dust & antioxidants & $\begin{array}{l}\text { solvents: } 70 \% \text { ethanol conditions: } \\
170 \mathrm{~W}, 40 \mathrm{~mL} / \mathrm{g}, 33 \mathrm{~s}\end{array}$ & $\begin{array}{l}40 \% \text { ethanol at room temperature } \\
(1: 10, v / v) \text { for } 48 \mathrm{~h}\end{array}$ & $\begin{array}{l}\text { increased total polyphenol content from } \\
135.26 \pm 1.72 \text { to } 237.74 \pm 2.08 \mathrm{mg} \mathrm{GAE} / \mathrm{g} \text {, } \\
\text { total flavonoid content from } 30.82 \pm 2.35 \\
\text { to } 42.95 \pm 1.32 \mathrm{mg} \text { quercetin equivalents } \\
\text { (QE)/g, } 2,2 \text {-diphenyl-1-picrylhydrazyl } \\
\text { (DPPH) radical scavenging activity } \\
\text { from } 21.58 \% \pm 0.88 \% \text { to } 71.72 \% \pm 2.12 \%\end{array}$ & [45] \\
\hline Quercus bark & polyphenols & $\begin{array}{l}\text { solvents: ethanol content } 33 \% \text {, methanol } \\
\text { content } 0.38 \% \text { conditions: } 50 \mathrm{~Hz}, 45 \mathrm{~W} \text {, } \\
60 \text { min, } \mathrm{pH} 10.75 \text {, room temperature }\end{array}$ & $\begin{array}{l}\text { the same extraction condition without } \\
\text { microwave treatment }\end{array}$ & $\begin{array}{l}\text { increased by } 3 \text { times and } 2 \text { times } \\
\text { respectively for total phenolic content } \\
\text { and antioxidant recoveries }\end{array}$ & [46] \\
\hline \multicolumn{6}{|c|}{ enzyme-assisted extraction (EAE) } \\
\hline wine making by-products & phenolics & $\begin{array}{l}\text { solvents: } 70 \% \text { acetone enzyme treatment } \\
\text { with } 2 \% \text { viscozyme solution stirred for } \\
12 \mathrm{~h} \text { at } 37^{\circ} \mathrm{C} \text { or } 1 \mathrm{mg} / \mathrm{mL} \text { pronase } \\
\text { solution stirred for } 1 \mathrm{~h} \text {, then extraction } \\
\text { with } 70 \%(v / v) \text { acetone in a gyratory } \\
\text { water bath shaker at } 30^{\circ} \mathrm{C} \text { for } 20 \mathrm{~min}\end{array}$ & $\begin{array}{l}\text { the same extraction protocol without } \\
\text { enzyme treatment }\end{array}$ & $\begin{array}{l}\text { pronase and viscozyme increased the } \\
\text { content of soluble phenolics while } \\
\text { reducing the content of } \\
\text { insoluble-bound phenolics }\end{array}$ & [32] \\
\hline grape skins & flavonoids & $\begin{array}{l}\text { solvents: buffer solution containing an } \\
\text { appropriate amount of enzyme } \\
\text { conditions: } 10.52 \mathrm{mg} / \mathrm{g} \text { Lallzyme EX-V, } \\
\mathrm{pH} 2.0 \text {, extraction at } 45^{\circ} \mathrm{C} \text { for } 3 \mathrm{~h}\end{array}$ & $\begin{array}{l}70 \% \text { aqueous ethanol containing } 1 \% \\
\text { formic acid for one day in the dark }\end{array}$ & $\begin{array}{l}\text { improved recovery of anthocyanin } \\
\text { contents (from } 40,496.19 \pm 58.18 \text { to } \\
41,752.95 \pm 76.10 \mathrm{mg} / \mathrm{kg} \text { ) and flavan-3-ol } \\
\text { contents (from } 329.32 \pm 2.46 \text { to } \\
345.94 \pm 2.88 \mathrm{mg} / \mathrm{kg} \text { ) }\end{array}$ & [47] \\
\hline tomato processing waste & lycopene & $\begin{array}{l}\text { solvents: hexane/acetone/ethanol } \\
(50: 25: 25 \mathrm{v} / \mathrm{v}) \text { conditions: } 1.5 \% \\
\text { cellulase } / 2 \% \text { pectinase at } 4 \mathrm{~h} \text { of } \\
\text { incubation period }\end{array}$ & without enzyme treatment & $\begin{array}{l}\text { increased the yield of lycopene } \\
\text { from less than } 200 \text { to } 847.33 \mu \mathrm{g} / \mathrm{g} \\
\text { (cellulase treatment) and to } \\
1262.56 \mu \mathrm{g} / \mathrm{g} \text { (pectinase treatment) }\end{array}$ & [48] \\
\hline
\end{tabular}


Table 1. Cont

\begin{tabular}{|c|c|c|c|c|c|}
\hline \multirow{2}{*}{ Source } & \multirow{2}{*}{ Compounds Extracted } & \multicolumn{2}{|c|}{ Extraction Parameters } & \multirow{2}{*}{ Extraction Improvement } & \multirow{2}{*}{ Reference } \\
\hline & & Non-Conventional Method & Conventional Methods & & \\
\hline \multicolumn{6}{|c|}{ pressurized liquid extraction (PLE) } \\
\hline $\begin{array}{l}\text { Aerial parts of } \\
\text { Dracoceph-alum kotschyi }\end{array}$ & phenolics and flavonoids & $\begin{array}{l}\text { solvents: methanol conditions: } 74^{\circ} \mathrm{C}, \\
34 \text { bar pressure, } 11.33 \text { min static time, } \\
17.45 \mathrm{~min} \text { dynamic time, and } 0.7 \\
\mathrm{~mL} / \mathrm{min} \text { solvent flow rate }\end{array}$ & $\begin{array}{l}\text { percolated with } 1.0 \mathrm{~L} \text { of methanol at } \\
\text { room temperature }\left(25^{\circ} \mathrm{C}\right) \text { according to } \\
\text { the European Pharmacopeia }\end{array}$ & $\begin{array}{l}\text { improved recovery of total phenolic (from } \\
22.29 \pm 0.05 \text { to } 30.92 \pm 0.03 \mathrm{GAE} \mathrm{mg} / \mathrm{g} \text { ), } \\
\text { total flavonoids (from } 5.042 \pm 0.04 \text { to } \\
6.13 \pm 0.07 \mathrm{QE} \mathrm{mg} / \mathrm{g} \text { ) and luteolin content } \\
\text { (from } 9550 \pm 0.3 \text { to } 13,247 \pm 0.2 \mu \mathrm{g} / \mathrm{g} \text { ) }\end{array}$ & [49] \\
\hline roots of Scutellaria pinnatifida & phenolics and flavonoids & $\begin{array}{l}\text { solvents: methanol conditions: } 65.8^{\circ} \mathrm{C} \text {, } \\
39.2 \text { bar pressure, } 12.9 \mathrm{~min} \text { static time, } \\
18.9 \mathrm{~min} \text { dynamic time, } \\
\text { and } 0.76 \mathrm{~mL} / \mathrm{min} \text { solvent flow rate }\end{array}$ & $\begin{array}{l}\text { percolated with } 1.0 \mathrm{~L} \text { of methanol } \\
\text { at room temperature }\end{array}$ & $\begin{array}{l}\text { the total phenolic content increased from } \\
196.66 \text { to } 396.94 \mathrm{mg} / \mathrm{g} \text {, and the total } \\
\text { flavonoid content increased } \\
\text { from } 91.3 \text { to } 127.78 \mathrm{mg} / \mathrm{g}\end{array}$ & [50] \\
\hline black bamboo leaves & antioxidants & $\begin{array}{l}\text { solvents: } 50 \% \text { ethanol for the total } \\
\text { phenolic (TP) and } 75 \% \text { ethanol for total } \\
\text { flavonoid (TF) and } 25 \% \text { ethanol for } \\
\text { DPPH radical scavenging ability } \\
\text { conditions: } 1500 \text { psi, } 200{ }^{\circ} \mathrm{C} \text {, } \\
25 \text { min static time }\end{array}$ & $\begin{array}{l}\text { reflux extraction method } \\
\left(\sim 90^{\circ} \mathrm{C}, 1 \mathrm{~L} \text { solvent, } 60 \mathrm{~min}\right)\end{array}$ & $\begin{array}{l}\text { improved extraction yields } \\
\text { from } 240 \text { to } 500 \mathrm{mg} / 1 \mathrm{~g} \text { Dry black bamboo } \\
\text { leaves (DL), TP contents from } 1510 \pm 3.2 \\
\text { to } 2682 \pm 0.9 \mathrm{mg} / 100 \mathrm{~g} \text {, TF contents from } \\
182 \pm 2.7 \text { to } 657 \pm 1.7 \mathrm{mg} / 100 \mathrm{~g}\end{array}$ & [51] \\
\hline palm pressed fiber & $\beta$-carotene & $\begin{array}{l}\text { solvents: n-hexane conditions: } 80^{\circ} \mathrm{C} \text {, } \\
1500 \text { psi, } 2 \times 10 \text { min static extractions } \\
\text { with flush volume } 50 \%\end{array}$ & $\begin{array}{l}\text { extracted with n-hexane and chloroform } \\
\text { in a Soxhlet apparatus for } 8 \mathrm{~h}\end{array}$ & $\begin{array}{l}\text { obtained total } \beta \text {-carotene and vitamin } \\
\text { contents comparable to Soxhlet extraction } \\
\text { but with lower total organic solvent and } \\
\text { rapid extraction process }\end{array}$ & [52] \\
\hline \multicolumn{6}{|c|}{ supercritical fluid extraction (SFE) } \\
\hline myrtle leaves and berries & antioxidants & $\begin{array}{l}\text { solvents: carbon dioxide conditions: } \\
23 \mathrm{MPa} 45^{\circ} \mathrm{C} \text { and a CO} 2 \text { flow of } \\
0.3 \mathrm{~kg} / \mathrm{h} \text { using absolute ethanol as } \\
\text { co-solvent with a flow rate of } 0.09 \mathrm{~kg} / \mathrm{h}\end{array}$ & $\begin{array}{l}\text { obtained by hydrodistillation } \\
\text { using a Clevenger-type } \\
\text { apparatus, for two hours }\end{array}$ & $\begin{array}{l}\text { increased antioxidant capacity } \\
\text { (about 20-40 times), polyphenolic contents } \\
\text { (about } 2 \text { times) and } \\
\text { myricetin-3-O-rhamnoside content } \\
\text { (about } 110-170 \text { times in fruit and } \\
\text { about } 130-210 \text { times in leaves) }\end{array}$ & [53] \\
\hline Prunus persica leaves & phenolic compounds & $\begin{array}{l}\text { solvents: carbon dioxide conditions: } \\
60^{\circ} \mathrm{C}, 150 \mathrm{bar} \text { and } 6 \% \text { ethanol } \\
\text { co-solvent at a flow rate of } 15 \mathrm{~g} / \mathrm{min} \\
\text { and for a duration of } 60 \mathrm{~min}\end{array}$ & $\begin{array}{l}\text { extracted } 3 \text { times with } 30 \mathrm{~mL} \text { of solvent } \\
\text { system (acetone:methanol:water:formic } \\
\text { acid, } 40: 40: 20: 0.1 \text { ) }\end{array}$ & $\begin{array}{l}\text { the radical scavenging activity value } \\
\text { increased from } 32.23 \% \text { to } 53.25 \%\end{array}$ & [54] \\
\hline \multicolumn{6}{|c|}{ high hydrostatic pressure extraction (HHPE) } \\
\hline $\begin{array}{l}\text { prickly pear beverages } \\
\text { prepared with } 10 \% \text { peel } \\
\text { and } 90 \% \text { pulp }\end{array}$ & Phyto-chemical Compounds & $\begin{array}{l}400 \text { or } 550 \mathrm{MPa} \text {, room } \\
\text { temperature, } 0-16 \mathrm{~min}\end{array}$ & thermally treated at $138 \pm 1^{\circ} \mathrm{C}$ for $2 \mathrm{~s}$ & $\begin{array}{l}\text { increased TP content }(16 \%-35 \%) \text { and } \\
\text { antioxidant activity }(8 \%-17 \%) \text { for Cristal } \\
\text { (A) and Rojo San Martin varieties as well } \\
\text { as increased the betaxanthin contents } \\
(6 \%-8 \%) \text { and betacyanin content }(4 \%-7 \%) \\
\text { for Rojo San Martin variety }\end{array}$ & [55] \\
\hline Panax ginseng & phenolic compounds & $600 \mathrm{MPa}$ for $1 \mathrm{~min}$ at room temperature & conventional steaming & $\begin{array}{l}\text { increased the total phenolic contents } \\
\text { (from } 1.13 \text { to } 1.37 \mathrm{mg} \text { maltol equivalent } / \mathrm{g} \\
\text { of red ginseng), especially maltol content } \\
(4.38 \text { to } 12.61 \mathrm{mg} / 100 \mathrm{~g} \text { of red ginseng), } \\
\text { also improved the ferrous ion chelating } \\
\text { and superoxide dismutase activities }\end{array}$ & [56] \\
\hline
\end{tabular}


Table 1. Cont

\begin{tabular}{|c|c|c|c|c|c|}
\hline \multirow{2}{*}{ Source } & \multirow{2}{*}{ Compounds Extracted } & \multicolumn{2}{|c|}{ Extraction Parameters } & \multirow{2}{*}{ Extraction Improvement } & \multirow{2}{*}{ Reference } \\
\hline & & Non-Conventional Method & Conventional Methods & & \\
\hline \multicolumn{6}{|c|}{ Pulsed electric field extraction (PEFE) } \\
\hline defatted canola seed cake & polyphenols & $10 \%$ ethanol $30 \mathrm{~V}, 30 \mathrm{~Hz}$ and $10 \mathrm{~s}$ & $\begin{array}{l}\text { microwave processing }(5 \mathrm{~min}, \\
\text { liquid/solid ratio of } 6.0 \text { and } 633.3 \mathrm{~W})\end{array}$ & $\begin{array}{l}\text { less solvent usage, } \\
\text { a shorter extraction time }\end{array}$ & [57] \\
\hline Borago officinalis L. leaves & polyphenols & $\begin{array}{l}\text { acidic water (pH } 1.5) 1 \text { to } 7 \mathrm{kV} / \mathrm{cm} \text {, } \\
15-150 \mu \mathrm{s}, 0.04 \text { to } 61.1 \mathrm{~kJ} / \mathrm{kg}\end{array}$ & $\begin{array}{l}\text { the same extraction without PEF } \\
\text { treatment }\end{array}$ & $\begin{array}{l}\text { increased the TPC }(1.3-6.6 \text { times }) \text { and } \\
\text { ORAC values }(2.0-13.7 \text { times })\end{array}$ & [58] \\
\hline orange peel & polyphenols & $\begin{array}{l}\text { distilled water } 5 \mathrm{kV} / \mathrm{cm} \text {, } \\
60 \mu \mathrm{s}, 0.06 \text { to } 3.77 \mathrm{~kJ} / \mathrm{kg}, \\
\text { pressurization at } 5 \text { bars for } 30 \mathrm{~min}\end{array}$ & $\begin{array}{l}\text { the same extraction } \\
\text { without PEF treatment }\end{array}$ & $\begin{array}{l}\text { increased the naringin content from } 1 \text { to } \\
3.1 \mathrm{mg} / 100 \mathrm{~g} \text { and hesperidin content } \\
\text { from } 1.3 \text { to } 4.6 \mathrm{mg} / 100 \mathrm{~g}\end{array}$ & [59] \\
\hline \multicolumn{6}{|c|}{ high voltage electrical discharges extraction (HVEDE) } \\
\hline olive kernel & phenolic compounds & $49 \%$ ethanol, $66 \mathrm{~kJ} / \mathrm{kg}, \mathrm{pH} 2.5$ & $\begin{array}{l}\text { PEF with electric field strength } \\
\mathrm{E}=13.3 \mathrm{kV} / \mathrm{cm} \text { and } \mathrm{UAE} \\
\text { at } 400 \mathrm{~W} \text { and } 24 \mathrm{kHz}\end{array}$ & $\begin{array}{l}\text { more effective polyphenol extraction } \\
\text { (255 mg GAE/L for HVEDE versus } \\
140 \text { and } 146 \mathrm{mg} \text { GAE/L for UAE } \\
\text { and PEFE, respectively) }\end{array}$ & [60] \\
\hline
\end{tabular}




\subsection{Ultrasound-Assisted Extraction (UAE)}

Ultrasound assisted extraction (UAE) has been applied widely in the last three decades as an efficient extraction method in the food and pharmaceutical industries [61]. The mechanism is based on the cavitation phenomenon. The spread of ultrasound in liquid systems is via a series of compression and rarefaction waves, which can induce the production of cavitation bubbles within the fluid $[62,63]$. The size of these bubbles grow over the period of a few cycles until reach a critical point, then these bubbles collapse and release a great quantity of energy, which would generate extreme temperatures (5000 K) and pressures (1000 atmospheres) at room temperature. During the ultrasound assisted extraction of bioactive components from plant materials, the high temperature and pressure would destroy the cell walls, facilitate the release of bioactive compounds from plant cell walls and enhance the mass transport. The heat transfer of UAE is from outside of the plant cell to the inside, which is in the opposite direction of microwave assisted extraction.

Ultrasound frequency, intensity, temperature, and time can directly affect both extraction efficiency and yields. In addition, types of solvent, solvent volume, as well as sample characteristics such as moisture content of the sample and particle size are also the important factors for effective extraction [64]. Ultrasound-assisted extraction of anthocyanins and phenolic compounds in mulberry (Morus nigra) pulp was performed by Espada-Bellido et al. [65]. Several extraction variables, including methanol concentration $(50 \%-100 \%)$, temperature $\left(10-70{ }^{\circ} \mathrm{C}\right)$, ultrasound amplitude $(30 \%-70 \%)$, cycle (0.2-0.7 s), solvent $\mathrm{pH}(3-7)$ and solvent-solid ratio (10:1.5-20:1.5) were optimized to obtain the high extraction yields. It was found that extraction temperature and solvent concentration were the most influential parameters for extraction of anthocyanins and phenolic compounds. Besides, different UAE conditions were suitable for different bioactive components. The optimum UAE conditions for anthocyanins are $76 \%$ methanol concentration, $12: 1.5$ solvent-solid ratio, $48{ }^{\circ} \mathrm{C}$ extraction temperature, cycle of $0.7 \mathrm{~s}$ and $70 \%$ ultrasound amplitude at $\mathrm{pH} 3$, while the optimum UAE conditions for phenolic compounds were $61 \%$ methanol concentration, $11: 1.5$ solvent-solid ratio, $64{ }^{\circ} \mathrm{C}$ extraction temperature, cycle of $0.7 \mathrm{~s}$ and $70 \%$ ultrasound amplitude at $\mathrm{pH} 7$. Under the UAE optimal conditions, the maximized extraction yields of total anthocyanins and total phenolic compounds were $149.95 \mu \mathrm{g} / \mathrm{g}$ and $1214.03 \mu \mathrm{g} / \mathrm{g}$, respectively. Compared with conventional extraction, UAE showed several merits in terms of extraction yield and extraction time. Polyphenols from apple pomace were extracted using conventional extraction and UAE methods [66]. The results showed that ultrasound-assisted extraction increased the catechin equivalents by more than $20 \%$ and the release of flavan-3-ols and procyanidins were also enhanced by more than $25 \%$ in only $45 \mathrm{~min}$. In another study, Liu et al. [67] used UAE and traditional boiling-water extraction methods to extract antioxidants from Xiao-chai-hu-tang extracts, a Chinese herbal prescription. Compared with traditional boiling-water extraction, the ultrasound-assisted extraction significantly increased the antioxidant activities of Xiao-chai-hu-tang extracts, and significantly enhanced the extraction efficiency of flavonoids and phenolics. In addition, in industrial scale, ultrasound-assisted extraction is regarded as a promising technique to take place of conventional procedure due to the less extraction time, higher extraction yield and lower operating temperature.

To increase extraction yields and reduce the energy consumption, some novel efficient ultrasound-assisted extraction techniques have been developed, such as pulsed ultrasound-assisted technique (PUAE), ultra-turrax based ultrasound-assisted extraction (UT-UAE), and ionic liquid-based ultrasonic-assisted extraction (IL-UAE). PUAE is the ultrasound-assisted extraction under the pulsed mode [68]. The ultrasonic processor is turned on and off intermittently when pulsed extraction is performed, thus causing lower heat generation compared with continuous ultrasound-assisted extraction (CUAE). In this case, PUAE is more suitable for the extraction of thermo-sensitive compounds than CUAE. Moreover, the PUAE technique can lower the risk of technological problems such as erosion of the tip. Pan et al. [69] investigated the effects of CUAE and PUAE as well as conventional solvent extraction on the extraction efficiency of phenolic compounds from pomegranate peel. The observed results have shown that in comparison with conventional solvent extraction, PUAE elevated the extraction yield by $22 \%$, and decreased the extraction time by $87 \%$. Additionally, 
PUAE had 50\% energy saving compared to CUAE. Additionally, the combination of ultra-turrax and UAE has been developed to extract bioactive compounds from plants because ultra-turrax can provide effective mass transfer and facilitate bioactive compounds flow into extraction solvent through producing a narrow and uniform particle size distribution. A UT-UAE method was firstly designed for extracting organic acids from plant materials [70]. The extraction yields of chlorogenic acid, caffeic acid, 3,4-dicaffeoylquinic acid, 3,5-dicaffeoylquinic acid and 4,5-dicaffeoylquinic acid by UT-UAE were 1.13-1.23 folds that of UTE (ultra-turrax extraction) and 1.49-1.65 folds that of UAE. Based on the mass transfer kinetics and particle size distribution experiments, it was observed that UT-UAE could uniform particle distribution and increase extraction speed. Furthermore, the combination of ionic liquids (ILs) with ultrasonic-assisted extraction can produce a synergetic effect. Tan et al. [71] extracted flavonoids from Apocynum venetum L. leaves by IL-UAE. Using the imidazolium IL [C $\left.\mathrm{C}_{4 \mathrm{mim}}\right]\left[\mathrm{N}(\mathrm{CN})_{2}\right]$ aqueous solution as solvent, a remarkable extraction efficiency of $93.35 \%$ were obtained. Compared to water and conventional organic solvents, ILs possess unique characteristics, such as high polarity, negligible volatility, wide electrochemical windows, high ionic conductivity and chemical stability.

\subsection{Microwave-Assisted Extraction (MAE)}

Microwave is an electromagnetic radiation. During MAE, microwave can deliver energy to solvent and plant matrix and the energy can be absorbed by molecules inside plants, particularly the polar molecules. The severe thermal, localized pressures and mechanical stress caused by microwave significantly change the physical properties of the cell walls and finally result in rupture of cell walls and release of target components [72,73]. Since microwave irradiation was applied for the first time in 1986, there have been various studies on MAE in the recovery of the antioxidants from plant materials $[37,74-76]$. MAE is not adaptable for the extraction of the thermally labile antioxidants due to the thermal effect from microwave irradiation, which might result in the reduction of extraction yield. In addition, MAE is only applicable to the extraction solvents that must be able to absorb microwaves.

Factors influencing MAE are the selection of appropriate solvent, the ratio of solvent to material, irradiation temperature, irradiation time, microwave power, and matrix characteristics [77,78]. The selection of solvent should be based on the solubility of analyte of interest and the capacity of solvent to absorb microwaves. The ratio of solvent to material is also an important factor that influences the extraction process. The volume of solvent need to be sufficient to soak the plant material completely in the solvent during the microwave irradiation process, whereas a higher ratio of solvent to material would not exhibit higher extraction efficiencies due to non-uniform distribution and exposure to microwaves. Irradiation temperature is another vital factor that influences the extraction process. The yield of bioactive components can be enhanced with an increase in the irradiation temperature, but there is a risk of destruction of thermolabile components. Irradiation time and microwave power are interactive variables that influence the extraction process. High power can increase the heating effect and decrease the microwave irradiation time, but also result in degradation of thermolabile components. The matrix characteristics such as particle size and the nature of material can influence the extraction of the components to a considerable extent. For example, the finer particle size of the sample can offer the larger surface area and the better penetration [77]. A great number of researches indicated that MAE exerts several advantages in comparison with conventional extraction methods, such as higher extraction yield, less solvent consumption and shorter extraction time $[72,79]$. Microwave-assisted extraction of polyphenols from Myrtus communis L. leaves was performed by Dahmoune et al. [76]. Authors optimized four parameters, ethanol concentration, solvent/solid ratio, irradiation time, and microwave power to obtain the highest extraction of polyphenols. It was concluded that ethanol concentration and liquid-to-solid ratio were the important parameters. In the study, conventional solvent extraction (CSE) took $2 \mathrm{~h}$ and consumed $50 \mathrm{~mL} / \mathrm{g}$ solvent to extract polyphenols from Myrtus communis L. leaves, while MAE took only $62 \mathrm{~s}$ and consumed $32 \mathrm{~mL} / \mathrm{g}$ solvent to extract polyphenols [76]. Under the MAE optimal conditions, the extraction yields of total phenolic (162.49 $\pm 16.95 \mathrm{mg}$ gallic acid equivalent GAE/g dry weight $(\mathrm{DW}))$, total flavonoid $(5.02 \pm 0.05 \mathrm{mg}$ quercetin equivalents $(\mathrm{QE}) / \mathrm{g})$, and condensed tannins $(32.65 \pm 0.01 \mathrm{mg} / \mathrm{g})$, 
were higher than those of conventional solvent extraction $(128.00 \pm 18.07 \mathrm{mg}$ GAE/g DW, $4.15 \pm 0.75 \mathrm{mg} Q E / g$, and $17.18 \pm 0.01 \mathrm{mg} / \mathrm{g}$, respectively).

Solvent-free microwave extraction (SFME) as a green technique has been developed recently in accordance with the same principle of MAE [80]. The in-situ water in plant cells absorbs the energy and is stimulated to rotate under a microwave treatment. The immediate dramatic change causes a subsequent pressure increase inside plant cells. Then, cell walls are broken down and the target molecules are released. The extraction proceeds under atmospheric pressure. For fresh plant samples, microwave energy is mostly absorbed by water naturally occurred in plant materials, whereas for dried plant samples, these samples should be moistened with water or other solvents, or microwave absorption media prior to extraction, for increasing the absorbance of microwave energy [72,81]. Primarily, SFME was mainly applied in extraction of antioxidant essential oil from aromatic herbs and spices, such as Rosmarinus officinalis, Origanum vulgare and AlgerianLaurus nobilis L. [81-83]. Lately, there are several reports regarding the SFME of antioxidants in plant materials, such as flavonoids from onions [84], phenolic antioxidants from Citrus deliciosa T. leaves [82], and natural antioxidants from sea buckthorn food by-products [85]. Besides, a protocol of pressurized solvent-free microwave assisted extraction (PSFME) method was developed for extraction of antioxidants from Hippophae rhamnoides L. berries [86]. The extracts obtained by PSFME showed the richest phenolic content compared with pressing, maceration and pressurized liquid extraction. Furthermore, MAE coupled with vacuum system has been developed to extract antioxidants from plant materials [72]. The vacuum in the extraction vessel is achieved by vacuum pump. The vacuum microwave assisted extraction can avoid or reduce degradation of thermolabile and oxygen-sensitive phytochemicals from plants compared to conventional open MAE, mainly due to the low $\mathrm{O}_{2}$ concentration and moderate or even low temperature in the extraction vessel $[72,87]$. The extraction of thermo- and oxygen-sensitive components under the vacuum condition usually showed a high extraction yield with low temperature.

\subsection{Enzyme-Assisted Extraction (EAE)}

Enzymes have the properties of high specificity and high efficiency. Enzyme-assisted extraction (EAE) is a potential green extraction method because of the mild extraction conditions and barely any effect on the environment [88]. The enzymes could degrade the compositions and destroy the structural integrity of plant cell wall, which enhance the release of bioactive compounds. Cellulase, pectinase, hemicellulase and $\beta$-glucosidase are extensively used in the EAE. These enzymes can be obtained from various materials such as bacteria, fungi, vegetable and fruit extracts, or animal organs [88,89]. EAE techniques have been shown to improve the extraction efficiencies for antioxidants including phenolics, flavonoids, anthocyanins, and carotenoids [47,48,90-92].

Types of enzymes, concentration, $\mathrm{pH}$, incubation temperature, incubation time, liquid to solid ratio and particle size are the key factors influencing extraction efficiency and yield [93]. Different enzymes degrade different substrates, and the concentration affects the extraction efficiency. Furthermore, the $\mathrm{pH}$ for enzymatic hydrolysis varies from enzyme to enzyme. The $\mathrm{pH}$ affects not only enzyme activity but also the dissociation of some bioactive components such as anthocyanin. Besides, liquid to solid ratio, incubation temperature and time are factors that should not be neglected during processing. Therefore, optimum extraction parameters vary from different plant materials and enzymes. Enzyme-assisted extraction of polyphenols from cauliflower (Brassica oleracea L. var. botrytis) outer leaves was performed by Nguyen et al. [91]. Different enzyme concentrations $(0 \%-5 \%$ enzyme/substrate ratio) for Viscozyme L and Rapidase, incubation temperatures (30 to $50{ }^{\circ} \mathrm{C}$ ), $\mathrm{pH}$ values ( 3.0 to 6.0$)$ and incubation times $(0$ to $24 \mathrm{~h}$ ) were studied. It was concluded that these parameters significantly affected the extraction yield of polyphenols. The optimal extraction processes for the enzyme treatment were: enzyme/substrate ratio of $0.2 \%$ for Viscozyme L and $0.5 \%$ for Rapidase, temperature $35^{\circ} \mathrm{C}$, and $\mathrm{pH}$ 4.0. As compared to the control without enzyme treatment $(457 \pm 23 \mathrm{mg}$ $\mathrm{GAE} / 100 \mathrm{~g} \mathrm{DW})$, the enzymatic treatments had marked impacts on the release of phenolic compounds (581 \pm 16 mg GAE/100 g DW using Viscozyme L, $604 \pm 9$ mg GAE/100 g DW using Rapidase). In another study, an EAE method was applied to the extraction of phenolic compounds from watermelon rind using the mixture of pectinase, protease, $\alpha$-amylase and $\beta$-glycosidase [92]. 
Four variables, enzyme concentration $(0.5 \%-6.5 \%), \mathrm{pH}(6-9)$, temperature $\left(25-75^{\circ} \mathrm{C}\right)$ and treatment time (30-90 $\mathrm{min}$ ), were studied to obtain optimum yield of polyphenols. The results obtained under optimum conditions $\left(2.24 \%\right.$ enzyme concentration, $6.58 \mathrm{pH}, 51.8^{\circ} \mathrm{C}, 30 \mathrm{~min}$ ) indicated that optimized EAE enhanced the release of antioxidant phenolics up to 3 folds as compared to conventional solvent extraction, with level of $173.70 \mathrm{mg}$ GAE/g FW (total phenolics), $279.96 \mathrm{mg}$ TE/g FW (TEAC) and $112.27 \mathrm{mg} / \mathrm{mL}$ (DPPH radical scavenging ability $\left(\mathrm{IC}_{50}\right)$ ). Nevertheless, the application of EAE exhibits some potential commercial and technical limitations [94]. For example, the price of enzymes is relatively high, which influences the application, and the activity of enzymes varies with the environmental factors such as temperature and nutrient availability, therefore this method needs further improvement for its application in industrial scale.

Recently, EAE coupling with ultrasound, microwave and high hydrostatic pressure extraction technique has been developed for further enhancing extraction yields. For example, Liu et al. [89] studied an enzyme-based ultrasonic/microwave-assisted extraction (EUMAE) method for extracting orcinol glucoside (a phenolic compound) from the rhizomes of Curculigo orchioides Gaertn. In this study, enzymatic hydrolysis and ultrasonic/microwave-assisted extraction (UMAE) were combined. Under the optimal extraction conditions, the extraction yield of orcinol glucoside using EUMAE was higher $(92.13 \%)$ than those of extracts obtained by hot water extraction $(65.11 \%)$, UAE (76.19\%), MAE $(73.37 \%)$ and UMAE (82.42\%). The results indicated that EUMAE showed a higher yield with less energy consumption, and better selectivity. In addition, enzymatic hydrolysis combined with high hydrostatic pressure (HPP) technique was developed for extracting tricin (a flavonoid) from rice hull [95]. The observed results indicated that $0.5 \%$ cellulase assisted hydrolysis prior to HPP extraction increased the tricin yield more than twice than that of extract obtained by traditional solvent extraction. Hydrolytic enzymes promote the release of intracellular compounds by rupturing the cell wall compositions and HPP extraction improves the extraction efficiency by increasing solvent permeability.

\subsection{Pressurized Liquid Extraction (PLE)}

PLE is based on the use of solvents at elevated temperature and pressure to extract target components from various matrices $[96,97]$. By elevating the pressure, the temperature of solvent under liquid state can be above its boiling point at normal temperature, which can enhance mass-transfer rate and promote the solubility of the analytes. The wide ranges of temperature from room temperature to $200{ }^{\circ} \mathrm{C}$ and pressure from 35 to 200 bar can be applied in PLE. When the extraction solvent is water, PLE is also called sub-critical water extraction (SWE). When the water is heated to $200-250{ }^{\circ} \mathrm{C}$ in SWE, it can be maintained in liquid state, while the dielectric constant $(\varepsilon)$ of water is decreased from 80 to 30-25, which is close to the dielectric constant of some organic solvents such as ethanol or methanol. The closed dielectric constants mean the similar polarity of the organic solvent. Although not viable for every application, the use of SWE can be regarded as an effective alternative to organic solvents in some applications. Due to free of organic solvents, SWE is perceived as the "greenest" of the PLEs [97].

The PLE method has been used to increase the extraction yields of various antioxidants from plant materials such as phenolic compounds [98], carotenoids [99], flavonoids [100] and anthocyanins [101]. This technique is a green extraction method due to its reduced solvent usage, less extraction time, less operation steps and light- and oxygen-free environment. The most important parameters in PLE are the extraction solvent, the temperature, the pressure, the static time and the number of cycles [102]. Some parameters such as purge time and flush volume are relatively fixed and high enough to ensure the recovery of components extracted. Several extraction solvents or mixture solvents can be used in PLE for their similarity to that of the target compounds. For example, ethanol was used as the solvent for extraction of polyphenols, while n-hexane was used as the solvent for extraction of $\beta$-carotene [51,52]. Temperature and pressure are also important extraction parameters. Higher temperatures decrease the viscosity and the surface tension of liquid solvents, thus allowing better penetration of the matrix particles and allowing the solvent to "wet" the sample matrix more thoroughly, while maximum temperature is limited by the degradation temperature of each bioactive component. Besides, the elevated pressure can force the solvent within the matrix pore to contact 
the target compounds and extract them. The static extraction time and the number of cycles are also the related extraction parameters. The static extraction time should be long enough to ensure contact between the target components and the solvent, and the number of cycles is the number of times that solvent is put into the extraction cell and kept in contact with the samples. Antioxidants from black bamboo leaves were extracted using PLE with ethanol/water as solvents [51]. Various temperature ranges $\left(40-200{ }^{\circ} \mathrm{C}\right)$, ethanol concentrations $(0 \%-100 \%)$, sample sizes $(0.425-6 \mathrm{~mm})$, and extraction time (5-25 $\mathrm{min}$ ) were used to identify the optimal conditions for extracting polyphenols and investigating the antioxidative activity. The results showed that for TP, the best extraction processes were a $0.425 \mathrm{~mm}$ size material at $200{ }^{\circ} \mathrm{C}$ and 1500 psi with $50 \%$ ethanol for $25 \mathrm{~min}$, while, for TF, the best extraction condition was a $4.75 \mathrm{~mm}$ size material at $200{ }^{\circ} \mathrm{C}$ and 1500 psi with $75 \%$ ethanol for $25 \mathrm{~min}$, for DPPH radical scavenging ability, the best extraction processes were a $425 \mu \mathrm{m}$ size material at $200{ }^{\circ} \mathrm{C}$ and 1500 psi with $25 \%$ ethanol for $25 \mathrm{~min}$. The optimal PLE method exhibited more than twice the extraction efficiency on the extraction yields (from 240 to $500 \mathrm{mg} / 1 \mathrm{~g}$ dry black bamboo leaves (DL)), TP (from $1510 \pm 3.2$ to $2682 \pm 0.9 \mathrm{mg} / 100 \mathrm{~g} \mathrm{DL}$ ), and TF (from $182 \pm 2.7$ to $657 \pm 1.7 \mathrm{mg} / 100 \mathrm{~g}$ DL) of the crude extract as compared to the reflux extraction method $\left(\sim 90^{\circ} \mathrm{C}, 1 \mathrm{~L}\right.$ solvent, $\left.60 \mathrm{~min}\right)$, using less extraction solvent $(13 \mathrm{~mL}$ instead of $1000 \mathrm{~mL})$ in less time ( $25 \mathrm{~min}$ instead of $60 \mathrm{~min}$ ). The superheated extraction process for black bamboo leaves elevated the antioxidant properties by reducing the solvent viscosity and surface tension as well as disrupting the black bamboo leaves matrix to increase the connection of solvent with phenolics and flavonoids. Furthermore, PLE is an automated extraction process, and the operation is simplified. PLE was compared with manual-liquid extraction for extraction of apple monomeric phenolics [103]. The effects of four independent extraction factors, including extraction solvents (pure methanol and acetone-water $(70: 30, v / v))$, sample mass $(50-550 \mathrm{mg})$, extraction duration (1-15 $\mathrm{min}$ ) and number of extraction cycles (1-3) were evaluated on these polyphenol concentrations (HPLC-DAD analysis). It was observed that optimal conditions varied with phenolic compound. For an extraction in favor of chlorogenic acid, hyperoside, quercitrin and ideain, the experimental conditions of two successive extractions with pure methanol from $50 \mathrm{mg}$ freeze-dried apple samples for $15 \mathrm{~min}$ using three extraction cycles were recommended. In comparison with manual methods, PLE has a better performance in reduction of the extraction time and the amount of extraction solvent and increase of the extracted phenolic compounds contents. Meanwhile, PLE is suggested as a better extraction method for unstable bioactive compounds affected easily by oxygen and light, such as trans-resveratrol [104]. Pineiro et al. [104] studied the stability of trans-resveratrol from grapes when subjected to the action of the high temperatures employed in PLE. It was observed that the recoveries of resveratrol reached to $99.5 \% \pm 5.7 \%$ at the highest assayed temperature $\left(150^{\circ} \mathrm{C}\right)$, which meant that the resveratrol was not degraded using the PLE due to the inert atmosphere employed and the absence of light. However, this technique is not free from limitations. Wianowska et al. [105] found that chlorogenic acid was unstable under PLE conditions. The main caffeoylquinic acid isomer, trans-5-O-caffeoylquinic acid, was suffered from isomerization, transesterification, hydrolysis, and reaction with water, even within the short duration of PLE.

\subsection{Supercritical Fluid Extraction (SFE)}

Supercritical fluid extraction (SFE) as a sustainable green technology has been extensively applied since the past decades. Over the critical pressure (pc) and temperature (Tc), the solvent can be transformed into the supercritical state, which shows liquid-like (solvent power, negligible surface tension) and gas-like (elevated diffusivity and low viscosity) properties [106-108]. Even though PLE and SFE have in common that they conduct under medium-to-high pressures, SFE operate using solvents at temperatures and pressures above their critical points, whereas PLE is based on the use of liquids at temperatures above their normal boiling points [64]. Compared with normal liquids, supercritical fluids could enhance transport properties, which can diffuse easily through solid materials and therefore obtain faster extraction rates [109]. SFE utilizes the outstanding physicochemical properties of supercritical fluids (SF) to extract target components from various matrices. SFE basically contains two major steps: firstly, the soluble compounds from the plant material are extracted by the 
supercritical solvent, then these compounds are separated from the supercritical solvent by rapidly reducing the pressure, increasing the temperature, or both [53].

SFE can be affected by numerous factors, such as solvent flow-rate, operating pressure, extraction temperature, amount of modifier, extraction time, whereas origin, particle size, chemical components, as well as the pretreatment conditions also influence the yield and the composition of the extract by SFE $[64,110]$. These extraction processes can be precisely optimized for maximizing extraction [110]. The selection of best-suited solvent for a certain application is determined by the technical viability, toxicity, cost, and solvation ability. Several solvents have been used as a supercritical solvent, such as propane, ethane, hexane, pentane, butane and carbon dioxide. The amount of solvent used in SFE is greatly smaller than the amount for any extraction process completed under low pressure, which is advocated. $\mathrm{CO}_{2}$ is the most frequently used supercritical solvent in SFE since it is nontoxic, available at a reasonable cost, preserves the extracts from atmospheric oxidation and has a moderate critical temperature [109]. Nevertheless, due to its low polarity, $\mathrm{CO}_{2}$ cannot completely dissolve high-polarity compounds from plant materials, thus co-solvents (also called modifiers) are generally used to enhance the extraction yield through increasing the solvent polarity of $\mathrm{CO}_{2}$. These co-solvents are polar molecules and used in small amounts, which vary from $1 \%$ to $15 \%$ [53,109]. Ethanol or ethanol aqueous is the mostly used co-solvents.

Studies on the supercritical fluid extraction of caffeic acid derivatives, phenolic compounds, flavonoids, anthocyanin, astaxanthin, carotenoids, lycopodine, terpenoids and other antioxidants from food and medicinal plants have been published [54,107,111-115]. For example, the extraction of anthocyanin and phenolic compounds from jamun fruits [112] was performed by supercritical carbon dioxide extraction. The effects of three independent variables (temperature, pressure and co-solvent flow rate) were estimated on the maximum extraction yield. It was observed that as the pressure increased from 100 to 162 bar, the extraction yields of total monomeric anthocyanin content (TMAC) and total phenolic content (TPC) increased with a mild slope, then the yields slightly decreased when the pressure exceeded 200 bar. As the extraction temperature increased from 40 to $50{ }^{\circ} \mathrm{C}$, the extraction yields of TMAC and TPC increased, but slowly decreased, when the temperature continued to be elevated. Additionally, the co-solvent ( $99.9 \%$ ethanol) flow rate increasing from 1 to $2 \mathrm{~g} / \mathrm{min}$ caused a higher extraction yield and reached a peak, while the extraction yield had no further significant improvement when co-solvent flow rate exceeded $2 \mathrm{~g} / \mathrm{min}$. Finally, pressure of $162 \mathrm{bar}$, temperature at $50{ }^{\circ} \mathrm{C}$ and co-solvent flow rate of $2.0 \mathrm{~g} / \mathrm{min}$ was selected as optimal values. Under the optimal SFE conditions, $231.28 \pm 0.76 \mathrm{mg} / 100 \mathrm{~g}$ for total monomeric anthocyanin content and $1143.051 \pm 1.58 \mathrm{mg}$ GAE$/ 100 \mathrm{~g}$ for total phenolic content (TPC) were obtained, and seven different anthocyanins as well as eight different bioactive phenolics were identified by HPLC analysis. In a study conducted by Liu et al. [116], the flavonoids from Calycopteris floribunda leaves were obtained using supercritical fluid extraction (SFE). The parameters of temperature and pressure were optimized. The results showed that higher total yield of SFE was achieved at lower temperature and higher pressure. The SFE at the $\mathrm{CO}_{2}$ flow rate of $1.5 \mathrm{~kg} / \mathrm{h}$ for approximately $300 \mathrm{~min}$ with pressure of $30 \mathrm{MPa}$ at $35{ }^{\circ} \mathrm{C}$ was compared with classical organic solvent extraction (CE) with $40 \%$ ethanol solution for $8 \mathrm{~h}$ at $70{ }^{\circ} \mathrm{C}$. The results showed that the highest global yield $(8.01 \%)$ was obtained using CE method, whereas the separation efficiency of pachypodol (a potential anticancer compound) from the extracts achieved by SFE was 3.7 times higher than that achieved by CE. The results indicated that SFE could increase the selectivity of some flavonoid components in the extraction process. In the case of carotenoids from persimmon (Diospyros kaki L.), the best extraction for xanthophylls (all trans-lutein, all-trans-zeaxanthin and all-trans-beta-cryptoxanthin) were found at 300 bars, $60{ }^{\circ} \mathrm{C}$, and $3 \mathrm{~mL} / \mathrm{min} \mathrm{CO}_{2}$ flow rate, whereas as a non-oxygenated carotenoid, all-trans-beta-carotene was better extracted at 100 bars, $40{ }^{\circ} \mathrm{C}$, and $1 \mathrm{~mL} / \mathrm{min} \mathrm{CO}_{2}$ flow rate [115]. Compared to other extraction methods, SFE have exhibited the higher extraction efficiency and lower extraction time. Talmaciu et al. [117] investigated the effects of different extraction techniques (SFE, UAE and conventional ethanolic extraction) on extraction of polyphenols from spruce bark as a waste from forestry industry. Supercritical fluid extraction was performed at $1200 \mathrm{psi}$ with pure $\mathrm{CO}_{2}$ and $70 \%$ ethanol as co-solvent for $60 \mathrm{~min}$, UAE was performed using $70 \%$ ethanol in an ultrasonic bath 
at $40{ }^{\circ} \mathrm{C}$ for $60 \mathrm{~min}$ and the ethanolic extraction was performed using $70 \%$ ethanol in a closed oven for 13 days at $40{ }^{\circ} \mathrm{C}$. Results showed that SFE significantly elevated the yield of total phenolic compounds (122.41 mg GAE/g) compared with ethanolic extraction (14.38 mg GAE/g) and UAE (33.48 mg GAE/g). In addition, the analysis of compounds by HPLC showed that SFE extracts contained higher extraction yield of phenolic compounds such as p-coumaric acid $(260.4073 \mathrm{mg} / \mathrm{L})$, catechin $(171.1765 \mathrm{mg} / \mathrm{L})$ and synapic acid (35.0534 mg/L), compared with UAE (99.4731, 112.084, $13.3618 \mathrm{mg} / \mathrm{L}$, respectively). Nonetheless, the high running cost of SFE technique limits the scale-up application. Thus, studies on the economic viability of SFE in large scale can make the SFE process economically sustainable. Solana et al. [118] conducted a large scale of SFE to obtain phenolic and glucosinolate extracts from rocket salad. Results have indicated that the lowest extraction running costs were achieved at $25 \mathrm{MPa}$ and $75^{\circ} \mathrm{C}, 67 \%$ of the total production costs came from the raw materials. The profitability analysis indicated that this method made the process competitive with the price of extracts obtained using organic solvents.

In order to further enhance extraction efficiency and selectivity of targeted compounds, SFE combined with different technologies have been developed [119,120]. Mushtaq et al. [120] developed a comprehensive enzyme-assisted supercritical fluid extraction (EASCFE) for extracting phenolic antioxidants from pomegranate peel. Results showed that the extracts obtained by EASCFE doubled recovery of crude extracts, elevated level of phenolic contents, and enhanced radical scavenging capacity and inhibition of linoleic acid peroxidation in comparison with the control. The appreciable level of vanillic, ferulic, and syringic acids were detected in EASCFE extracts. The pretreatment with enzymes promoted cell wall hydrolysis and supercritical fluid extraction accelerated the mass transfer rate, which both led to a higher extraction yields and selectivity $[109,113]$. Additionally, the combination of SFE with ultrasound has been also developed. In a study, supercritical $\mathrm{CO}_{2}$ assisted by ultrasound was applied to extract antioxidant compounds from blackberry bagasse [119]. It was shown that the application of ultrasound increased its global yield at the pressure of $15 \mathrm{MPa}$, without affecting the quality of the extracts. Scanning electron microscopy image analyses indicated that ultrasound could rupture the cell walls, facilitating the release of the bioactive compounds. The results confirmed that coupling ultrasound with SFE processes would be a feasible technology to increase extraction efficiency, decrease extraction time and operational cost. Because of the synergistic effects, the combination of several techniques would be promising green processes for the optimal extraction of bioactive components in the future.

\subsection{Others}

High hydrostatic pressure extraction (HHPE) is a novel non-thermal technology to strengthen mass transport [121,122]. During HHPE, the cold isostatic super high hydraulic pressure varies from 100 to $800 \mathrm{MPa}$ or even more up to $1000 \mathrm{MPa}$. Under high pressure, the great differential pressure between the interior and exterior of cell membranes forms, and this accelerates the solvent penetration into cells through the broken membranes and increases the mass transfer rate, which indicates that the higher the hydrostatic pressure is, the more components can be released and the higher yield of extraction can be obtained [122]. The energy consumption (higher pressure) can enhance the extraction efficiency, while it can also increase the cost. At present, pressures up to $600 \mathrm{MPa}$ have the technical limitation for industrial scale [123]. Main factors influencing the HHPE are pressure, time, temperature, solvent types and liquid/solid ratio. A study was performed by Xi et al. [124] to extract polyphenols from green tea leaves using a high hydrostatic pressure extraction method. Various extraction variables in the HHPE procedure, such as different solvents (acetone, methanol, ethanol and water), pressure (100-600 MPa), holding time (1-10 $\mathrm{min})$, ethanol concentration ( $0 \%-100 \%)$, and liquid/solid ratio (10:1-25:1 mL/g), were evaluated. The optimal extraction yield of polyphenols ( $30 \% \pm 1.3 \%$ ) were obtained under the conditions of 50\% of ethanol concentration, 20:1 of liquid/material ratio and $500 \mathrm{MPa}$ of high hydrostatic pressure for $1 \mathrm{~min}$, which were comparable to those of heat reflux extraction for $45 \mathrm{~min}$, ultrasonic extraction for $90 \mathrm{~min}$ and extraction at room temperature for $20 \mathrm{~h}$, respectively. These data showed that the HHPE is more effective compared with the conventional 
extraction ones. Additionally, higher ferulic acid extraction yield from Angelica sinensis radix and higher flavonoid and anthocyanins recovery from red grape skin have also been found using HHPE [125-127].

Apart from the extraction techniques mentioned above, disintegration of the cell membrane in plant materials by pulsed electric field (PEF) technology also has been suggested as a non-thermal extraction method to enhance the extraction yield of bioactive molecules from plants. Pulsed electric fields technique is based on the application of short duration pulses of high electric field intensity $(0.1-50 \mathrm{kV} / \mathrm{cm})$ at room temperature [128]. Electric fields of few to several hundred microseconds are capable of inducing pore formation in the cell membrane, which is called "electroporation". Based on this, subsequent extraction of bioactive molecules can be carried out [129]. Zderic and Zondervan [129] showed that the increment of temperature did not exceed $10^{\circ} \mathrm{C}$ during the extraction of polyphenol from fresh tea leaves using PEF. This slight temperature increment confirmed that pulsed electric field processing provided a non-thermal condition. The improvement of extraction efficiency using PEF technology has been demonstrated in the extraction of antioxidants from food and medicinal plants, such as polyphenols from Norway spruce bark [130]; anthocyanin from blueberry processing by-products [131]; quercetin and ellagic acid from Emblica officinalis juice [132]; anthocyanin from red cabbage [133]; lutein from Chlorella vulgaris [134]; and beta-carotene from carrot pomace [135]. The electric field strength plays an important role in solute extraction. Lopez et al. [136] researched the effects of PEF at 5 and $10 \mathrm{kV} / \mathrm{cm}$ on the extraction of phenolic compounds during the fermentation of must of Tempranillo grapes. Results showed that the permeabilization of the grape skin using PEF treatment at room temperature increased the anthocyanin and polyphenolic content compared to the control during all the vinification process. The anthocyanins contents improved from $835.29 \mathrm{mg} / \mathrm{L}$ to $965.02 \mathrm{mg} / \mathrm{L}(5 \mathrm{kV} / \mathrm{cm})$ and $1056.06 \mathrm{mg} / \mathrm{L}(10 \mathrm{kV} / \mathrm{cm})$ with the PEF treatment, while, the total phenolic index increased significantly from 70.65 OD $280 \mathrm{~nm}$ to $83.1 \mathrm{OD} 280 \mathrm{~nm}(5 \mathrm{kV} / \mathrm{cm})$ and 87.7 OD $280 \mathrm{~nm}$ $(10 \mathrm{kV} / \mathrm{cm})$ with the PEF treatment. Additionally, PEF did not influence wine characteristics such as alcohol content, total acidity, reducing sugar concentration, and the ratio between the compositions of the red wine color (tint and yellow, red and blue components).

As another electrical treatment technology, high voltage electrical discharges (HVED) technique has been also developed for biomolecules extraction from various products [137]. Under high-current/high voltage electrical discharge, a plasma channel is formed between two submersed electrodes and the energy can be directly injected into an aqueous solution. It induces physical processes and chemical reactions including the production of shock waves, the emission of high-intensity UV light and the generation of hydroxyl radicals via water photodissociation. Shock waves lead to mechanical rupture of cell membranes, UV light between 200 and $400 \mathrm{~nm}$ is mutagenic to cells, and hydroxyl radicals cause oxidative damage of cells, which promote the release of bioactive compounds from inside cells [137]. The method has been applied to vegetative raw material, such as vine shoot, green tea, linseed, sesame seed and root of Datura Innoxia [138-140]. The high voltage electrical discharges assisted extraction is a green extraction technique as it can enhance the rate of extracted biocompounds at reduced time, low temperature and energy input [137]. Boussetta et al. [138] investigated the effects of high voltage electrical discharges (HVED) on the aqueous extraction of polyphenols from grape pomace (Vitis vinifera L.) at mild temperature $\left(20-60{ }^{\circ} \mathrm{C}\right)$. The results showed that the yield of extracted solutes $(70 \%)$ from fresh grape pomace with HVED extraction after 40 min was more than twice the yield (about $30 \%$ ) obtained after $240 \mathrm{~min}$ without HVED. HVED after $1 \mathrm{~h}$ also increased the yield of polyphenols $\left(Y_{\text {polyphenols }}=0.44 \% \pm 0.07 \%\right)$ compared to that $\left(Y_{\text {polyphenols }}=0.26 \% \pm 0.06 \%\right)$ of extraction without HVED after $4 \mathrm{~h}$. Nevertheless, this method may be accompanied by some negative effects. Boussetta and Vorobiev [130] reported that the use of HVED can produce very small particles, which can render the subsequent solid to liquid separation step more difficult.

How to choose a suitable extraction process for natural antioxidant(s): The selection of a suitable extraction process for natural antioxidant(s) is the result of a comprehensive consideration regarding extraction efficiency, economic feasibility and environment aspects of non-conventional extraction techniques. Comparison of non-conventional extraction techniques is displayed in Table 2. Extraction efficiency of non-conventional extraction techniques is clearly advantageous compared with 
the conventional extraction methods in case of time, energy, and extraction yield. Nevertheless, the extraction efficiencies among non-conventional extraction techniques are different (Table 2). In a study, the comparison of extraction efficiencies between UAE and EAE was carried out by Le et al. [141]. It was observed that the levels of vitamin C, phenolics and antioxidant activity evaluated by DPPH and 2,2'-azinobis-(3-ethylbenzothiazoline-6-sulphonic acid) (ABTS) methods in UAE were, respectively, 4.6\%, 3.5\%, 4.6\% and 3.3\% higher than those in EAE. Obviously, UAE is more effective for the extraction of antioxidant compounds from acerola (Malpighia emarginata DC.) fruit. In another study, the comparison of extraction efficiencies between UAE and MAE was conducted [74]. The results showed that the optimized MAE gave higher extraction yields compared with UAE in case of total phenolic, total flavonoids and tannins content from the leaves of Pistacia lentiscus L. Furthermore, Rodriguez-Perez et al. [142] emphasized that in the extraction of kaempferol, quercetin, and their glucosides derivatives, MAE seemed to be more efficient compared to PLE, whereas PLE was a better choice for the extraction of phenolic compounds with a higher number of hydroxyl-type substituents such as kaempferol diglycoside and its acetyl derivatives as well as those that are sensitive to high temperatures (glucosinolates or amino acids). Moreover, Rosello-Soto et al. [61] indicated that HVEDE was more effective than UAE and PEFE in case of polyphenol extraction (255 mg GAE/L for HVED compared with 140 and $146 \mathrm{mg}$ GAE/L for US and PEF, respectively).

Apart from possessing high extraction efficiency, the extraction methods must show their economic feasibility. Factors affecting the investment cost include direct manufacturing costs (e.g., instrument, raw materials and operational labor), fixed costs (e.g., depreciation and insurance), as well as general expenses (e.g., administration costs and development) [64]. The overall investment costs for the extraction of antioxidants using non-conventional techniques can be high or low (Table 2). $\mathrm{UAE}$ and MAE is recommended as the most feasible and economically profitable extraction method in the large scale due to not high investment cost as well as competitive energy efficiency [62]. Although the potential of PLE, SFE, HHPE, PEFE and HVEDE for energy efficient can be clearly observed, the high capital, maintenance and service costs make their application keep in lab- or pilot-scale [123].

Based on the green chemistry and sustainable development concepts, many efforts have been made to provide not only highly efficient, but also eco-friendly methods for the extraction of antioxidants from food and medicinal plants [64]. These non-conventional extraction technologies are conducted with less or no usage of harmful organic solvents. Among non-conventional extraction technologies mentioned above, supercritical fluid extraction, especially supercritical $\mathrm{CO}_{2}$ extraction and sub-critical water extraction are recommended. The amount of solvent used in SFE is greatly smaller than that of any extraction process completed under low pressure. $\mathrm{CO}_{2}$ is the most frequently used supercritical solvent in SFE since it is nontoxic and available at a reasonable cost [109]. Although not viable for every application, the use of SWE can be regarded as an effective alternative to organic solvents in some applications. Due to free of organic solvents, SWE is perceived as the "greenest" of the PLEs [97].

How to design extraction process of natural antioxidant(s): Different types of antioxidants (phenolic acids, flavonoids, anthocyanins and carotenoids) can be extracted using non-conventional extraction techniques through adjusting extraction conditions according to the characteristics of components and matrices. Numerous factors have impacts on an extraction process, such as solvent choice, temperature, particle size of sample, pressure, extraction time. Optimization of the process conditions is important for achieving high extraction efficiency and making the final product suitable for different applications. In the preliminary/single factor study, the influence of factors on extraction efficiency/bioactivity needs to be investigated independently. The variables that affect the extraction efficiency/bioactivity significantly are selected for subsequent optimization design. To optimize the significant factors and obtain optimum results with minimum experimental trials, screening experimental designs and optimization experimental designs are used [110]. Screening designs can be used to analyze the most important factors and their interactions from all potential factors. Two-level full factorial, two-level factorial and Plackett-Burman design are frequently used for screening purposes. Optimization designs are used to confirm the optimal conditions of the experiment. Central composite design (CCD), Box-Behnken design (BBD), Taguchi design and Doehlert design are frequently used for optimization purposes [110,143]. 
Table 2. Comparison of non-conventional extraction techniques.

\begin{tabular}{|c|c|c|c|c|c|c|}
\hline Method & Brief Description & Investment Cost & Energy Efficiency & Merits & Drawbacks & Reference \\
\hline $\begin{array}{l}\text { ultrasound-assisted } \\
\text { extraction }\end{array}$ & $\begin{array}{l}\text { Sample is extracted with solvent } \\
\text { in a vessel and immersed in an } \\
\text { ultrasonication bath. }\end{array}$ & low & medium & $\begin{array}{l}\text { fast energy transfer; high } \\
\text { extraction yield; low solvent use; } \\
\text { short extraction time (5-60 min) }\end{array}$ & $\begin{array}{l}\text { lack of uniformity in the process; } \\
\text { generating damages to the ear of } \\
\text { the operator; filtration and } \\
\text { clean-up step required. }\end{array}$ & {$[64,65,144,145]$} \\
\hline $\begin{array}{l}\text { microwave -assisted } \\
\text { extraction }\end{array}$ & $\begin{array}{l}\text { Sample is extracted with a } \\
\text { microwave absorbing solvent in } \\
\text { a closed/open vessel and } \\
\text { irradiated with microwave. }\end{array}$ & medium & medium & $\begin{array}{l}\text { quick heating for bioactive } \\
\text { compounds extraction; high } \\
\text { extraction yield; low solvent use; } \\
\text { moderate extraction time } \\
(1 \mathrm{~min}-40 \mathrm{~min})\end{array}$ & $\begin{array}{l}\text { Extraction solvent must be able } \\
\text { to absorb microwaves; filtration } \\
\text { and cleanup step required. }\end{array}$ & {$[64,75,145]$} \\
\hline $\begin{array}{l}\text { enzyme-assisted } \\
\text { extraction }\end{array}$ & $\begin{array}{l}\text { Sample and enzyme solution } \\
\text { are loaded into a vessel and } \\
\text { placed in a water bath } \\
\text { thermostated at the certain } \\
\text { temperature and time. }\end{array}$ & medium & medium & $\begin{array}{l}\text { moderate extraction conditions; } \\
\text { eco-friendly; selectivity due to the } \\
\text { specificity of enzymes }\end{array}$ & $\begin{array}{l}\text { Expensive cost of enzymes; } \\
\text { activity of enzymes varying } \\
\text { with the environmental factors; } \\
\text { filtration and } \\
\text { cleanup step required. }\end{array}$ & {$[88,91,94]$} \\
\hline $\begin{array}{l}\text { pressurized liquid } \\
\text { extraction }\end{array}$ & $\begin{array}{l}\text { Sample and solvent are heated } \\
\text { and pressurized in a vessel with } \\
\text { elevated temperature and } \\
\text { pressure. After finishing the } \\
\text { extraction, the extract is } \\
\text { automatically into a vial. }\end{array}$ & high & high & $\begin{array}{l}\text { high extraction yield; low time and } \\
\text { solvent consumption; protection } \\
\text { for oxygen and light sensitive } \\
\text { compounds; no filtration required; } \\
\text { automated systems }\end{array}$ & $\begin{array}{l}\text { clean-up step required; } \\
\text { expensive equipment required. }\end{array}$ & {$[96,145]$} \\
\hline $\begin{array}{l}\text { supercritical fluid } \\
\text { extraction }\end{array}$ & $\begin{array}{l}\text { Sample is extracted } \\
\text { with super-critical fluid in a } \\
\text { vessel with high pressure. the } \\
\text { analytes are collected in a small } \\
\text { volume of solvent or onto a } \\
\text { solid-phase trap. }\end{array}$ & high & high & $\begin{array}{l}\text { green solvents (e.g., } \mathrm{CO}_{2} \text { ) used; } \\
\text { high extraction yield; better } \\
\text { separation of solute from solvent; } \\
\text { possibility to on-line combining } \\
\text { with chromato-graphic process; } \\
\text { reduced the thermal degradation; } \\
\text { no cleanup or filtration required; } \\
\text { automated systems }\end{array}$ & $\begin{array}{l}\text { limited ability to dissolve } \\
\text { polar compounds; more } \\
\text { parameters to optimize. }\end{array}$ & {$[64,106,107,117,145]$} \\
\hline $\begin{array}{l}\text { high hydrostatic } \\
\text { pressure extraction }\end{array}$ & $\begin{array}{l}\text { Sample was mixed with } \\
\text { solvent and placed in a sterile } \\
\text { poly-ethylene bag, which is } \\
\text { eliminated air from the inside } \\
\text { and placed into a pressure } \\
\text { extractor at different } \\
\text { pressure values. }\end{array}$ & high & high & $\begin{array}{l}\text { waste-free process; short time } \\
\text { (only about } 5 \mathrm{~min} \text { ); performed at } \\
\text { room temperature without } \\
\text { any heating process }\end{array}$ & $\begin{array}{l}\text { High investment cost and } \\
\text { cost-intensive maintenance and } \\
\text { service, which make industrial } \\
\text { application difficult. }\end{array}$ & {$[123,127,146]$} \\
\hline $\begin{array}{l}\text { pulsed electric } \\
\text { field extraction }\end{array}$ & $\begin{array}{l}\text { Extraction was performed } \\
\text { between two plate electrodes } \\
\text { with } 2-3 \mathrm{~cm} \text { distance and the } \\
\text { sample is placed in the } \\
\text { treatment chamber. }\end{array}$ & high & high & $\begin{array}{l}\text { mild (non-thermal) processing } \\
\text { method; short time (less than } 1 \mathrm{~s} \text { ) }\end{array}$ & $\begin{array}{l}\text { Extraction must be applied to } \\
\text { food products that can } \\
\text { withstand high electric } \\
\text { fields and have low } \\
\text { electrical conductivity. }\end{array}$ & {$[129,146,147]$} \\
\hline $\begin{array}{l}\text { high voltage electrical } \\
\text { discharges extraction }\end{array}$ & $\begin{array}{l}\text { HVED treatment was performed } \\
\text { between the stainless steel } \\
\text { needle and the grounded plate } \\
\text { electrodes with } 1 \mathrm{~cm} \text { distance } \\
\text { and the sample is placed in the } \\
\text { treatment chamber. }\end{array}$ & high & high & $\begin{array}{l}\text { mild (non-thermal) processing } \\
\text { method; high extraction efficiency; } \\
\text { short extraction time }\end{array}$ & $\begin{array}{l}\text { High voltage electrical } \\
\text { discharges may generate } \\
\text { chemical products and free } \\
\text { reactive radicals, which can } \\
\text { react with antioxidant } \\
\text { compounds, thus decreasing } \\
\text { their bioactive activity. }\end{array}$ & [147] \\
\hline
\end{tabular}




\section{Assessment Methods of Antioxidant Capacity}

Assessment of antioxidant capacity of natural products has been regarded as a basis for ranking the antioxidant plants and recommending best antioxidant foods for consumption. The evaluation of antioxidant activity of food and medicinal plants can be performed using chemical-based assays and cellular-based assays.

\subsection{Chemical-Based Assays}

Numerous chemical-based assays have been developed to evaluate the activity of antioxidants in foods and medicinal plants. These assays can roughly be classified into two types according to the mechanism: single electron transfer (SET) and hydrogen atom transfer (HAT) [148-150]. SET-based methods measure the ability of an antioxidant to transfer one electron to reduce target charged compounds, such as radicals, and metal ions. Among these SET-based assays, some assays are based on the ability to scavenge the stable free radicals, such as Trolox equivalence antioxidant capacity (TEAC), DPPH assay and Folin-Ciocalteu regent assay, and some assays are based on the ability to reduce metal ions, such as ferric ion reducing antioxidant power (FRAP), and cupric reducing antioxidant capacity (CUPRAC). Meanwhile, HAT-based assays detect the ability of an antioxidant to quench free radicals by hydrogen donation, which are more relevant to the radical chain-breaking antioxidant capacity. HAT-based assays include oxygen radical absorbance capacity (ORAC), total radical trapping antioxidant parameter (TRAP), and inhibiting the oxidation of low-density lipoprotein (LDL).

\subsubsection{Scavenging Free Radicals Assays}

The Trolox equivalent antioxidant capacity (TEAC) assay is widely applied to evaluate the antioxidant ability to scavenge the ABTS radical [148,149,151,152]. According to the type of oxidation agent, there are two versions of this assay [153]. TEAC1: metmyoglobin $-\mathrm{H}_{2} \mathrm{O}_{2}$ oxidize ABTS to generate its colored $\mathrm{ABTS} \bullet^{+}$form; then, subsequent addition of antioxidants results in loss of the green color. TEAC2: potassium persulfate oxidize ABTS to generate its colored $\mathrm{ABTS}^{+}{ }^{+}$form; then, subsequent addition of antioxidants results in loss of the green color. The version of TEAC1 is inaccurate because antioxidants also can react with the original $\mathrm{HO} \bullet$ radical and the metmyoglobin except for the ABTS $\bullet^{+}$, which could cause an overestimation of antioxidant capacity. Therefore, the version of TEAC2 is more preferable. ABTS $\bullet^{+}$has a UV-vis absorption maximum at $734 \mathrm{~nm}$. The decrease of absorbance can be monitored spectrophotometrically. The difference of the absorbance tested is plotted versus the antioxidants concentrations. The antioxidant capacity was expressed as Trolox equivalents. Because $\mathrm{ABTS}^{+}{ }^{+}$could react rapidly with antioxidants, the assay possesses the merits of rapidity and simplicity. Additionally, $\mathrm{ABTS} \bullet^{+}$is not influenced by ionic strength and is solvable in both organic and aqueous solvents, so it can be applied in multiple media to detect both hydrophilic and lipophilic antioxidant activities [154]. However, for slow reactions, the TEAC values tested is inaccurate when the duration of reaction is beyond $6 \mathrm{~min}$ [149].

As one of the few stable organic nitrogen radicals, the 2,2-diphenyl-1-picrylhydrazyl (DPPH) radical is used to analyze the antioxidant activity $[151,155]$. The DPPH• posses a deep purple color and has a UV-vis absorption maximum at $515 \mathrm{~nm}$ [148,149]. The test compounds (antioxidants) reduce DPPH radical to DPPH-H and the solution color fades. The reducing ability can be assessed by measuring the decrease of its absorbance. In the end, the results are shown by $\mathrm{EC}_{50}$ and $\mathrm{TEC}_{50}$, that is, the necessary amount of antioxidant to decrease the initial DPPH concentration by $50 \%$ and the time taken to reach the steady state to $\mathrm{EC}_{50}$ concentration [155]. DPPH assay is widely used in antioxidant capacity screening of fruit and vegetable juices or extracts, for it is easy, rapid and requires only a UV-vis spectrophotometer to test. Compared with ABTS assay, the DPPH radical is commercially available and does not have to be generated before assay such as ABTS $\bullet^{+}$. However, the application of DPPH assay is limited by its disadvantage. The linear reaction range of DPPH assay is narrow, only 
2-3-fold. Moreover, for steric inaccessibility, antioxidants that possess strong antioxidant activities in lipid peroxidation system may react slowly or may even be inert to DPPH [148,149].

\subsubsection{Reducing the Metal Ions Assays (FRAP and CUPRAC Assays)}

The ferric-reducing antioxidant power (FRAP) assay measures directly the reducing capacity of antioxidants. In ferric-reducing antioxidant reactive system, the antioxidants can reduce a ferric tripyridyltriazine complex $\left(\mathrm{Fe}^{3+}-\mathrm{TPTZ}\right)$ to the ferrous complex $\left(\mathrm{Fe}^{2+}-\mathrm{TPTZ}\right)$ under $\mathrm{pH} 3.6$ condition with a blank sample in parallel. The ferrous complex ( $\mathrm{Fe}^{2+}$-TPTZ) is blue ferrous form and has a UV-vis absorption maximum at $593 \mathrm{~nm}$. The ability of antioxidants in samples (FRAP value) is positive related to the increase in absorbance [151,156-158]. In general, this assay is suitable for some antioxidants that complete the reaction rapidly within 4 to $6 \mathrm{~min}$, such as ascorbic acid and uric acid [159]. However, it has been demonstrated that the absorption of several dietary polyphenols in water and methanol slowly increased even after several hours, such as tannic acid, and caffeic acid [157]. In addition, FRAP cannot detect compounds that act by radical quenching ( $\mathrm{H}$ transfer), particularly thiols and proteins. This results in a serious underestimation in serum sample [149].

The cupric reducing antioxidant capacity (CUPRAC) assay is similar to the FRAP method. CUPRAC method is conducted by mixing $\mathrm{Cu}$ (II)-neocuproine (Nc) chelate with antioxidant solution. The absorbance of the color $\mathrm{Cu}(\mathrm{I})$-chelate as a result of redox reaction is measured at $450 \mathrm{~nm}$ after $30 \mathrm{~min}$ [160]. The application on this assay is less extensive than FRAP. However, this assay exhibits several merits in some ways. For example, the reagent in this assay is useful at $\mathrm{pH} 7$, which is at physiological pH (as opposed to the Folin and FRAP assays, which work at $\mathrm{pH} 10$ and $\mathrm{pH}$ 3.6, respectively). This method could be applied for the determination of both hydrophilic and lipophilic antioxidants because the $\mathrm{Cu}(\mathrm{II})-\mathrm{Nc}$ is soluble in both aqueous and organic environments (unlike Folin and DPPH) [160,161]. In addition, CUPRAC assay can measure the reducing power of thiol-type antioxidants, such as glutathione and nonprotein thiols [150,162].

\subsubsection{Folin-Ciocalteu Reagent (FCR) Assay}

Folin-Ciocalteu reagent (FCR) assay is a widespread method for quantitative determination of phenolic compounds. The mechanism of Folin-Ciocalteu method is electron transfer (ET) $[134,135]$. It involves reducibility of phenols in alkaline solution $(\mathrm{pH}=10)$, which is capable of turning yellow molybdotungsto-phosphoric heteropolyanion reagent into the blue resultant molybdotungsto-phosphate $[148,163,164]$. These blue pigments have a maximum absorption in the 700-760 $\mathrm{nm}$ range. The maximum absorption depends on the qualitative and/or quantitative composition of phenolic mixtures. The total phenols assay by FCR is simple, convenient, and has produced a large body of comparable data. Thus, it has become a routine assay in studying phenolic antioxidants from fruits, vegetables and medicine plants [163,165-168]. A large number of publications found excellent linear correlations between the "total phenolic profiles" by FCR and "the antioxidant activity" by other ET-based antioxidant capacity assay (e.g., FRAP, TEAC, etc.) $[148,169,170]$.

\subsubsection{Oxygen Radical Absorbance Capacity (ORAC) Assay}

Generally, these assays estimate the capacity of antioxidants to protect a target molecule exposed to a free radical source. The oxygen radical absorbance capacity (ORAC) assay has been applied widely in the field of antioxidant and oxidative stress via $\mathrm{H}$ atom transfer $[148,149,171,172]$. In the basic assay, the peroxyl radical mixes with a fluorescent probe (FL; $3^{\prime}, 6^{\prime}$-dihydroxyspiro[isobenzofuran$1[3 \mathrm{H}], 9^{\prime}[9 \mathrm{H}]$-xanthen]-3-one), then form a nonfluorescent product, which can be quantitated easily by fluorescence $[149,171,173]$. When an antioxidant is added into the mixture, peroxyl radical induced oxidation is inhibited and the decay of FL is prevented. Antioxidant capacity is reflected by determining the decreased rate and amount of product formed over time. Using AUC (area under curve) to reflect the antioxidant capacity is favorable because it applies to an antioxidant that has a lag phase or one that do not [171]. It is useful for a broad range of sample types, including raw fruit and 
vegetable extracts, plasma, and pure phytochemicals. Furthermore, the high-throughput assay is able to test several hundred samples daily by just using one plate-reader coupled with a multichannel automatic liquid handling system [148].

\subsubsection{Total Radical Trapping Antioxidant Potential (TRAP) Assay}

The total radical trapping antioxidant potential (TRAP) assay measures the ability of antioxidants to suppress the oxidation progress of 2,2'-azobis-2-methyl-propanimidamide, dihydrochloride (AAPH) or 2,2'-azobis(2-amidinopropane) dihydrochloride (ABAP) [148,174]. The variation in the reaction progress is monitored fluorometrically $\left(\lambda_{\mathrm{ex}}=495 \mathrm{~nm}\right.$ and $\left.\lambda_{\mathrm{em}}=575 \mathrm{~nm}\right)$. The fluorescence decay rate in the reaction slows after the addition of antioxidants compared with the rate before the antioxidants addition. The quantification is based on the lag-phase duration compared with the lag phase of Trolox $[149,162]$. The application of the lag phase is based on the assumption that the antioxidants show a lag phase and the length of the lag phase is positively correlated to antioxidant capacity. However, not every antioxidant component possesses an obvious lag phase and the potential of antioxidants that play a role after the lag phase is totally ignored.

\subsubsection{Inhibiting the Oxidation of Low-Density Lipoprotein (LDL) Assay}

Inhibition of induced lipid autoxidation has been developed as a measure of antioxidant capacity in a more physiologically relevant system [148-150]. Usually, the reaction solution contains free radical initiator (Cu(II) or 2,2'-azobis(2-amidinopropane) dihydrochloride (AAPH)), substrate (linoleic acid or LDL), and antioxidants. The autoxidation of linoleic acid or LDL is induced by $\mathrm{Cu}(\mathrm{II})$ or AAPH. The peroxidation of the lipid components is monitored at $234 \mathrm{~nm}$ by UV spectrometer for conjugated dienes. In the presence of a radical initiator, the reaction starts and the absorbance at $234 \mathrm{~nm}$ increases as the evidence of the accumulation of conjugated diene oxides. After the addition of antioxidants, the reaction rate slows down until the antioxidant is exhausted. In the period, the lag time is measured and used to evaluate antioxidant capacity.

Compared with other in vitro assays, the major advantage of this method is the use of a biological relevant substrate, which makes the results relevant to oxidative reactions in vivo [149]. Because LDL is isolated from blood samples, one of the major flaws of this method is the variability of the LDL samples, which can vary with different donors. Thus, this method is hard to be developed as a consistent, reproducible, high throughput antioxidant evaluation assay [148-150]. On the contrary, using linoleic acid or its methyl ester as an oxidation substrate would make the results more reproducible than using LDL. However, linoleic acid would form micelles in the presence of water, and the reaction progress in micelles cannot be monitored directly by UV absorbance, thus the accuracy of the method can be affected.

\subsection{Cellular-Based Assays}

The antioxidant capacity evaluated by chemical assays cannot completely reflect the behavior of the sample in vivo. It is necessary to estimate the effectiveness of antioxidants in more biologically relevant conditions. Animal models and human studies are more suitable for evaluation but more expensive and time-consuming [150]. As intermediate testing methods, cellular antioxidant activity (CAA) assay has been developed for evaluating the antioxidant capacities $[175,176]$. Dichlorofluorecin $(\mathrm{DCFH})$ method is a commonly used CAA assay, which tests the capacity of antioxidants to prevent the oxidation of DCFH. In general, DCFH trapped within cells is easily oxidized to fluorescent dichlorofluorescein (DCF) by ABAP-generated peroxyl radicals in human hepatocarcinoma HepG2 cells. DCF could be monitored by fluorescence $\left(\lambda_{\mathrm{exc}}=485 \mathrm{~nm}, \lambda_{\mathrm{em}}=538 \mathrm{~nm}\right.$ ). The decrease in cellular fluorescence is proportional to the antioxidant capacity of bioactive components. Except for HepG2 cells, several cell types have been applied for the CAA assay, such as human red blood cell, human endothelial EA.hy926, human colon cancer Caco-2 cell, human macrophage U937 cell and mouse macrophage RAW264.7 cell $[150,176,177]$. Besides, a CAA assay based on microfluidic cell chip 
with arrayed microchannels has been developed to assess plant antioxidants [178]. The microfluidic chip contains 288 round cell culture micro chambers and 48 independent parallel array channels. In this method, eight groups of different samples with six different concentrations could be tested simultaneously with multimode reader.

The assessment of antioxidant activity at cellular level is not limited to the test of ability of ROS/RNS scavenging but also includes tests of expression of antioxidant enzymes, inhibition of pro-oxidant enzymes, and activation vs. repression of redox transcription factors [150]. The antioxidant activities of the extracts prepared from five brown seaweeds was assessed in Caco-2 cells. Glutathione (GSH) content and antioxidant enzyme activity (catalase (CAT) and superoxide dismutase (SOD)) were evaluated. These cellular assays indicated that Pelvetia canaliculata could exert the antioxidant capacity mainly by preventing $\mathrm{H}_{2} \mathrm{O}_{2}$-mediated SOD depletion in Caco-2 cells [179]. Besides, antioxidant enzyme activities of glutathione peroxidase (GPx) and glutathione reductase (GR) were measured in three Argentinean red wines. Some protective effects of wine were observed in cells exposed to $\mathrm{H}_{2} \mathrm{O}_{2}$, which was attributed to the increased activity of antioxidant enzymes GPx and GR [180]. In addition, suppression of NF- $\mathrm{KB}$ activation as an anti-oxidant response has been observed in cultured cells with the treatment of phenols (e.g., curcumin) or food extracts (e.g., blueberries) $[150,181,182]$. In a study, it was observed that the activation of NF- $\mathrm{kB}$ and activator protein-1, as well as IL-8 release were suppressed in curcumin-treated alveolar epithelial cells. Additionally, in comparison with untreated cells, the levels of GSH and glutamylcysteine ligase catalytic subunit mRNA expression were increased [181].

\section{Main Resources of Natural Antioxidants}

Among various chemical based assays, the TEAC assay evaluates the ability to scavenge the free radical, the FRAP assay measures directly the reducing capacity of antioxidants, the total phenols assay by FCR assesses the phenolic contents from tested samples. To comprehensively study different aspects of antioxidants, the combination of TEAC, FRAP and FCR methods is frequently used to evaluate the antioxidant activity. As shown in Table 3, the antioxidant activities of many food and medicinal plants have been widely estimated, e.g., fruits, vegetables, cereal grains, edible and wild flowers, macro-fungi, medicinal plants, spices, etc., and the varieties showing strong antioxidant activities were displayed in Table 3 based on a combinative consideration of the results obtained by FRAP, TEAC and FCR assays. Overall, these results showed that different categories exhibited diverse antioxidant capacities and the variation was very large. The FRAP, TEAC and FCR values of 62 fruits varied from $0.11 \pm 0.01$ to $72.11 \pm 2.19 \mu \mathrm{mol} \mathrm{Fe}(\mathrm{II}) / \mathrm{g}, 0.84 \pm 0.03$ to $80.68 \pm 2.11 \mu \mathrm{mol}$ Trolox $/ \mathrm{g}$, and $11.88 \pm 0.11$ to $585.52 \pm 18.59 \mathrm{mg}$ GAE $/ 100 \mathrm{~g}$, respectively [11]. The FRAP, TEAC and FCR values of 56 vegetables varied from 2.69 to $60.9 \mu \mathrm{mol} \mathrm{Fe(II)/g,} 6.93$ to $33.63 \mu \mathrm{mol}$ Trolox/g, and 4.99 to $23.27 \mathrm{mg} \mathrm{GAE} / \mathrm{g}$, respectively [14]. The FRAP, TEAC and FCR values of 24 cereal grains varied from $5.23 \pm 0.23$ to $126.19 \pm 2.91 \mu \mathrm{mol} \mathrm{Fe}(\mathrm{II}) / \mathrm{g}, 0.62 \pm 0.14$ to $30.03 \pm 1.10 \mu \mathrm{mol}$ trolox $/ \mathrm{g}$, and $1.35 \pm 0.15$ to $9.47 \pm 0.48 \mathrm{mg}$ GAE/g, respectively [12]. The FRAP, TEAC and FCR values of 223 medicinal plants varied from 0.14 to $1844.85 \mu \mathrm{mol} \mathrm{Fe}(\mathrm{II}) / \mathrm{g}$, 0.99 to $1544.38 \mu \mathrm{mol}$ Trolox/g, and 0.19 to $101.33 \mathrm{mg}$ GAE/g, respectively [15]. Obviously, among these varieties showing strong antioxidant activities, the antioxidant activities and total phenolic contents of medicinal plants were significantly higher than those of fruits, vegetables and cereals.

Additionally, the antioxidant activities of food and medicinal plants have also been evaluated by cellular antioxidant activity assays based on different cell types, and the varieties showing strong antioxidant activities were displayed in Table 3 . The cellular antioxidant activities of 27 vegetables ranged from not detected (tomato) to $41.9 \pm 6.2 \mu \mathrm{mol}$ of $\mathrm{QE} / 100 \mathrm{~g}$ (beet) [183]. The cellular antioxidant activities of 25 fruits ranged from $3.15 \pm 0.21$ (banana) to $292 \pm 11 \mu \mathrm{mol}$ of QE/100 g (wild blueberry) [184]. In both studies, these results showed that CAA values were significantly associated with total phenolic content. Surarit et al. [185] reported that the ethanolic bran extracts of 11 Thai pigmented (red and purple) and two non-pigmented rice varieties exerted the cellular 
antioxidant activities based on HL-60 cells in the following order: red > purple $>$ non-pigmented rice, which showed the same order of phenolic and flavonoid contents in these rice extracts.

\subsection{Natural Sources of Polyphenols}

Polyphenols are abundant in food and medicinal plants, including phenolic acids, flavonoids, lignans, and stilbenes [20].

Phenolic acids comprise of derivatives of cinnamic acid (e.g., p-coumaric, caffeic, and ferulic) and derivatives of benzoic acid (e.g., gallic acid and hydroxybenzoic acids). Compared with the hydroxybenzoic acids, the hydroxycinnamic acids are more abundant in edible plants [20]. Fruits such as blueberries, kiwis, plums, cherries, apples are found to be rich in the hydroxycinnamic acids (0.5-2 $\mathrm{g}$ hydroxycinnamic acids $/ \mathrm{kg}$ fresh $\mathrm{wt}$ ). Caffeic acid is the most abundant phenolic acid and account for $75 \%-100 \%$ of the total hydroxycinnamic acid content in many fruits, whereas, ferulic acid is the most abundant phenolic acid in cereal grains and account for about $90 \%$ of total polyphenol content of wheat grain. The hydroxybenzoic acid content in edible plants is usually very low, except for certain red fruits, black radish, and onions. Due to the low content, they are not considered to be of great nutritional interest.

Flavonoids are abundant in most edible fruits and vegetables. Its subclasses include flavonols, flavanones, catechins, flavones, anthocyanidins and isoflavonoids. The concentration and type of flavonoids vary in different dietary sources [186]. Quercetin is usually the most abundant flavonol in edible plants. The richest dietary source of quercetin is onion. Tea and wine have relatively low amounts of quercetin. Other flavonols include myricetin (berries), isorhamnetin (onion), and kaempferol (broccoli). Flavanones almost only exist in citrus fruits. Hesperidin and narirutin are the main flavonoids of oranges and mandarins, whereas, naringin and narirutin are the main flavonoids of grapefruit. Catechins usually exist in the form of aglycones or esterified with gallic acid. The richest dietary sources of catechins are tea and red wine. In addition, the major flavones are apigenin and luteolin. The major dietary sources are red pepper and celery. Anthocyanins, such as pelargonidin, cyanidin, and delphinidin, contribute to the red, blue, or violet color of edible plants, such as plums, eggplant, and many berries. The isoflavonoids, such as isoflavones genistein and daidzein, mainly exist in legumes. The richest dietary source are soybean and soy products [186,187].

The richest dietary source of lignans is linseed containing secoisolariciresinol (up to $3.7 \mathrm{~g} / \mathrm{kg}$ dry wt) and low quantities of matairesinol [20]. Other algae, leguminous plants (lentils), cereals (triticale and wheat), fruit (pears, prunes) and certain vegetables (garlic, asparagus, carrots) also have traces of these same lignans. Resveratrol is a stilbene, which has been extensively studied for its multiple bioactivities. Red wine is rich in resveratrol (0.3-7 mg aglycones/L and $15 \mathrm{mg}$ glycosides/L).

\subsection{Natural Sources of Carotenoids}

Carotenoids are natural pigments, including $\beta$-carotene, lycopene, lutein, and zeaxanthin [188]. All colorful edible plants, especially dark green and yellow-orange leafy, are the good sources of carotenoids. Due to the lipid solubility of carotenoids, the absorption mainly depends on their preparation with oils or fats. Among the carotenoids, the $\beta$-carotene commonly occurs in edible plants that possesses the highest activity of provitamin A, such as acerola, mango, pumpkin, carrot, nuts, and oil palm. Lycopene is a kind of red pigment. It almost exists only in vegetables and algae tissues. Tomato products such as juices, soups, sauces, and ketchup, as well as their processing waste and peel are important sources of lycopene [189]. The lycopene (79\%-91\%) presented in tomatoes is mostly in the form of the trans isomer. Lutein and zeaxanthin are the most common xanthophylls in green and dark leafy vegetables such as broccoli, spinach, peas and lettuce [190]. Zeaxanthin also found in the red marine microalga P. cruentum (making up $97.4 \%$ of the total carotenoids) (Mezzomo et al., 2016; Raposo et al., 2015) [188,191]. 
Table 3. The antioxidant capacities of some foods and medicinal plants.

\begin{tabular}{|c|c|c|c|}
\hline Category & Varieties Showing Strong Antioxidant Activities & Assessment Method & Reference \\
\hline \multicolumn{4}{|l|}{ antioxidant activities at chemical level } \\
\hline 26 spices & oregano, cinnamon stick, clove, cinnamon, sage & $\begin{array}{l}\text { Trolox equivalent antioxidant capacity (TEAC), } \\
\text { Folin-Ciocalteu reagent (FCR) }\end{array}$ & [8] \\
\hline 62 fruits & $\begin{array}{l}\text { Chinese date, pomegranate, guava, sweetsop, persimmon, } \\
\text { Chinese wampee and plum, grape (red) }\end{array}$ & TEAC, ferric-reducing antioxidant power (FRAP), FCR & [11] \\
\hline 24 cereal grains & black rice, red rice, purple rice, buckwheat & TEAC, FRAP, FCR & [12] \\
\hline 49 Edible macro-fungi & $\begin{array}{l}\text { Thelephora ganbajun, Boletus edulis, } \\
\text { Volvariella volvacea, Boletus regius, and Suillus bovinus }\end{array}$ & TEAC, FRAP, FCR & [13] \\
\hline 56 vegetables & $\begin{array}{l}\text { Chinese toon Bud, loosestrife, perilla leaf, cowpea, caraway, } \\
\text { lotus root, sweet potato leaf, soy bean (green), } \\
\text { pepper leaf, ginseng leaf, chives, and broccoli }\end{array}$ & TEAC, FRAP, FCR & [14] \\
\hline 223 medicinal plants & $\begin{array}{l}\text { Acanthopanax gracilistylus, Agrimonia pilosa, Anemarrhena asphodeloides, } \\
\text { Caesalpina sappan, Carthamus tinctorius, Dioscorea bulbifera, Fraxinus } \\
\text { rhynchophylla, Lonicera japonica (flower), Magnolia officinalis, Mentha } \\
\text { haplocalyx, Paeonia lactiflora (red), Polygonum multiflorum (Stem), } \\
\text { Polygonum multiflorum (Root), Rhodiola sacra, Salvia miltiorrhiza, } \\
\text { Tussilago farfara, Sargentodoxa cuneata }\end{array}$ & TEAC, FRAP, FCR & [15] \\
\hline 51 edible and wild flowers & $\begin{array}{l}\text { Rosa rugosa, Limonium sinuatum, Pelargonium hortorum, } \\
\text { Jatropha integerrima and Osmanthus fragrans, Orostachys fimbriatu, } \\
\text { Chaenomeles sinensis, Calliandra haematocephala }\end{array}$ & TEAC, FRAP, FCR & [16] \\
\hline 50 fruit wastes & $\begin{array}{l}\text { grape seed, hawthorn peel, longan peel, longan seed, } \\
\text { mango peel, Chinese olive peel and sweetsop peel }\end{array}$ & TEAC, FRAP, FCR & [19] \\
\hline \multicolumn{4}{|l|}{ antioxidant activities at cellular level } \\
\hline 27 vegetables & beet, broccoli, and red pepper, eggplant, Brussels sprout, cabbage & cellular antioxidant activity (CAA) based on HepG2 cells & [183] \\
\hline 25 fruits & $\begin{array}{l}\text { pomegranate and berries (wild blueberry, } \\
\text { blackberry, raspberry, and blueberry) }\end{array}$ & CAA based on HepG2 cells & [184] \\
\hline $\begin{array}{l}11 \text { Thai pigmented (red and purple) and } \\
2 \text { nonpigmented rice varieties }\end{array}$ & $\begin{array}{l}\text { hawm dowk mali deang (red), hawm deang sukhothai1 (red), } \\
\text { hawm deang (red), man pu (red), red rose (red), } \\
\text { klam moang (purple), klam chiang mai (purple) }\end{array}$ & CAA based on HL-60 cells & [185] \\
\hline 13 food legumes & black soybean, black bean, pinto bean, lentil, green pea, yellow soybean & CAA based on human gastric adenocarcinoma AGS cells & [192] \\
\hline 12 plantago species & P. lanceolata, P. himalaica, $P$. depressa, $P$. cornuti, $P$. jehohlensis & CAA based on HepG2 cells & [193] \\
\hline seven cultivars of Aloe & Aloe. greenii, Aloe. arborescens & CAA based on HepG2 cells & [194] \\
\hline five main Phyllanthus emblica L. cultivars & qingyougan, binggan and boligan & CAA based on HepG2 cells & [195] \\
\hline
\end{tabular}




\section{Conclusions}

Antioxidants derived from food and medicinal plants have been increasingly investigated for their various nutritional function and health benefits. In this review, the extraction methods of natural antioxidants, assessment methods of antioxidant activity as well as their main resources from food and medicinal plants are summarized. The non-conventional techniques described have potential to replace or enhance existing extraction techniques due to the less extraction time, energy consumption, and usage of harmful organic solvents, as well as higher extraction yields to recover antioxidant compounds from food and medicinal plants. Nevertheless, most of them are limited for industrial applications due to the high equipment costs and complicated installation procedures. Thus, establishing the balance between energetic and cost will be a key research in the future. To take advantage of the different extraction methods and to limit their drawbacks, the combinative application of multiple extraction technologies and the automated potential of these non-conventional extraction technologies would be the development tendency in future. For assessing the antioxidant activity of plant materials, several assays are suggested, such as the determination of total polyphenolic content by FCR, scavenging free radical ability by TEAC, metal-reducing activity by FRAP, and a kind of cellular-based assay. Furthermore, in order to make the comparison of different samples and studies possible, standardizing the operating conditions of the same analysis method and the expression of results are recommended.

Acknowledgments: This work was supported by the National Natural Science Foundation of China (No. 81372976), Key Project of Guangdong Provincial Science and Technology Program (No. 2014B020205002), and the Hundred-Talents Scheme of Sun Yat-Sen University.

Author Contributions: Dong-Ping $\mathrm{Xu}$ and Hua-Bin Li conceived this paper; Dong-Ping Xu and Ya Li wrote this paper; and Xiao Meng, Tong Zhou, Yue Zhou, Jie Zheng, Jiao-Jiao Zhang and Hua-Bin Li revised the paper.

Conflicts of Interest: The authors declare no conflict of interest.

\section{References}

1. Fang, Y.Z.; Yang, S.; Wu, G. Free radicals, antioxidants, and nutrition. Nutrition 2002, 18, 872-879. [CrossRef]

2. Peng, C.; Wang, X.; Chen, J.; Jiao, R.; Wang, L.; Li, Y.M.; Zuo, Y.; Liu, Y.; Lei, L.; Ma, K.Y.; et al. Biology of ageing and role of dietary antioxidants. BioMed Res. Int. 2014, 2014, 831841. [CrossRef] [PubMed]

3. Li, S.; Tan, H.Y.; Wang, N.; Zhang, Z.J.; Lao, L.; Wong, C.W.; Feng, Y. The role of oxidative stress and antioxidants in liver diseases. Int. J. Mol. Sci. 2015, 16, 26087-26124. [CrossRef] [PubMed]

4. Wang, F.; Li, Y.; Zhang, Y.J.; Zhou, Y.; Li, S.; Li, H.B. Natural products for the prevention and treatment of hangover and alcohol use disorder. Molecules 2016, 21, 64. [CrossRef] [PubMed]

5. Zhou, Y.; Zheng, J.; Li, S.; Zhou, T.; Zhang, P.; Li, H.B. Alcoholic beverage consumption and chronic diseases. Int. J. Environ. Res. Public Health 2016, 13, 522. [CrossRef] [PubMed]

6. Baiano, A.; del Nobile, M.A. Antioxidant compounds from vegetable matrices: Biosynthesis, occurrence, and extraction systems. Crit. Rev. Food Sci. Nutr. 2015, 56, 2053-2068. [CrossRef] [PubMed]

7. Cai, Y.Z.; Luo, Q.; Sun, M.; Corke, H. Antioxidant activity and phenolic compounds of 112 traditional Chinese medicinal plants associated with anticancer. Life Sci. 2004, 74, 2157-2184. [CrossRef] [PubMed]

8. Shan, B.; Cai, Y.Z.; Sun, M.; Corke, H. Antioxidant capacity of 26 spice extracts and characterization of their phenolic constituents. J. Agric. Food Chem. 2005, 53, 7749-7759. [CrossRef] [PubMed]

9. $\mathrm{Fu}, \mathrm{L}$; $\mathrm{Xu}$, B.T.; Gan, R.Y.; Zhang, Y.; Xu, X.R.; Xia, E.Q.; Li, H.B. Total phenolic contents and antioxidant capacities of herbal and tea infusions. Int. J. Mol. Sci. 2011, 12, 2112-2124. [CrossRef] [PubMed]

10. Fu, L.; Xu, B.T.; Xu, X.R.; Qin, X.S.; Gan, R.Y.; Li, H.B. Antioxidant capacities and total phenolic contents of 56 wild fruits from south China. Molecules 2010, 15, 8602-8617. [CrossRef] [PubMed]

11. $\mathrm{Fu}, \mathrm{L}$; $\mathrm{Xu}$, B.T.; Xu, X.R.; Gan, R.Y.; Zhang, Y.; Xia, E.Q.; Li, H.B. Antioxidant capacities and total phenolic contents of 62 fruits. Food Chem. 2011, 129, 345-350. [CrossRef]

12. Deng, G.F.; Xu, X.R.; Guo, Y.J.; Xia, E.Q.; Li, S.; Wu, S.; Chen, F.; Ling, W.H.; Li, H.B. Determination of antioxidant property and their lipophilic and hydrophilic phenolic contents in cereal grains. J. Funct. Food. 2012, 4, 906-914. [CrossRef] 
13. Guo, Y.J.; Deng, G.F.; Xu, X.R.; Wu, S.; Li, S.; Xia, E.Q.; Li, F.; Chen, F.; Ling, W.H.; Li, H.B. Antioxidant capacities, phenolic compounds and polysaccharide contents of 49 edible macro-fungi. Food Funct. 2012, 3, 1195-1205. [CrossRef] [PubMed]

14. Deng, G.F.; Lin, X.; Xu, X.R.; Gao, L.L.; Xie, J.F.; Li, H.B. Antioxidant capacities and total phenolic contents of 56 vegetables. J. Funct. Food 2013, 5, 260-266. [CrossRef]

15. Li, S.; Li, S.K.; Gan, R.Y.; Song, F.L.; Kuang, L.; Li, H.B. Antioxidant capacities and total phenolic contents of infusions from 223 medicinal plants. Ind. Crop. Prod. 2013, 51, 289-298. [CrossRef]

16. Li, A.N.; Li, S.; Li, H.B.; Xu, D.P.; Xu, X.R.; Chen, F. Total phenolic contents and antioxidant capacities of 51 edible and wild flowers. J. Funct. Food 2014, 6, 319-330. [CrossRef]

17. Li, Y.; Zhang, J.J.; Xu, D.P.; Zhou, T.; Zhou, Y.; Li, S.; Li, H.B. Bioactivities and health benefits of wild fruits. Int. J. Mol. Sci. 2016, 17, 1258. [CrossRef] [PubMed]

18. Zhang, J.J.; Li, Y.; Zhou, T.; Xu, D.P.; Zhang, P.; Li, S.; Li, H.B. Bioactivities and health benefits of mushrooms mainly from China. Molecules 2016, 21, 938. [CrossRef] [PubMed]

19. Deng, G.F.; Shen, C.; Xu, X.R.; Kuang, R.D.; Guo, Y.J.; Zeng, L.S.; Gao, L.L.; Lin, X.; Xie, J.F.; Xia, E.Q. Potential of fruit wastes as natural resources of bioactive compounds. Int. J. Mol. Sci. 2012, 13, 8308-8323. [CrossRef] [PubMed]

20. Manach, C.; Scalbert, A.; Morand, C.; Remesy, C.; Jimenez, L. Polyphenols: Food sources and bioavailability. Am. J. Clin. Nutr. 2004, 79, 727-747. [PubMed]

21. Jenab, M.; Riboli, E.; Ferrari, P.; Sabate, J.; Slimani, N.; Norat, T.; Friesen, M.; Tjonneland, A.; Olsen, A.; Overvad, K.; et al. Plasma and dietary vitamin C levels and risk of gastric cancer in the European Prospective Investigation into Cancer and Nutrition (EPIC-EURGAST). Carcinogenesis 2006, 27, 2250-2257. [CrossRef] [PubMed]

22. Li, A.N.; Li, S.; Zhang, Y.J.; Xu, X.R.; Chen, Y.M.; Li, H.B. Resources and biological activities of natural polyphenols. Nutrients 2014, 6, 6020-6047. [CrossRef] [PubMed]

23. Arathi, B.P.; Raghavendra-Rao Sowmya, P.; Vijay, K.; Baskaran, V.; Lakshminarayana, R. Metabolomics of carotenoids: The challenges and prospects-A review. Trends Food Sci. Technol. 2015, 45, 105-117. [CrossRef]

24. Zhang, Y.J.; Gan, R.Y.; Li, S.; Zhou, Y.; Li, A.N.; Xu, D.P.; Li, H.B. Antioxidant phytochemicals for the prevention and treatment of chronic diseases. Molecules 2015, 20, 21138-21156. [CrossRef] [PubMed]

25. Wojtunik-Kulesza, K.A.; Oniszczuk, A.; Oniszczuk, T.; Waksmundzka-Hajnos, M. The influence of common free radicals and antioxidants on development of Alzheimer's disease. Biomed. Pharmacother. 2016, 78, 39-49. [CrossRef] [PubMed]

26. Balmus, I.M.; Ciobica, A.; Trifan, A.; Stanciu, C. The implications of oxidative stress and antioxidant therapies in inflammatory bowel disease: Clinical aspects and animal models. Saudi J. Gastroenterol. 2016, 22, 3-17. [CrossRef] [PubMed]

27. Prasad, K.N. Simultaneous activation of Nrf2 and elevation of antioxidant compounds for reducing oxidative stress and chronic inflammation in human Alzheimer's disease. Mech. Ageing Dev. 2016, 153, 41-47. [CrossRef] [PubMed]

28. Salomone, F.; Godos, J.; Zelber-Sagi, S. Natural antioxidants for non-alcoholic fatty liver disease: Molecular targets and clinical perspectives. Liver Int. 2016, 36, 5-20. [CrossRef] [PubMed]

29. Zhou, Y.; Li, Y.; Zhou, T.; Zheng, J.; Li, S.; Li, H.B. Dietary natural products for prevention and treatment of liver cancer. Nutrients 2016, 8, 156. [CrossRef] [PubMed]

30. Zhou, Y.; Zheng, J.; Li, Y.; Xu, D.P.; Li, S.; Chen, Y.M.; Li, H.B. Natural polyphenols for prevention and treatment of cancer. Nutrients 2016, 8, 515. [CrossRef] [PubMed]

31. Zheng, J.; Zhou, Y.; Li, Y.; Xu, D.P.; Li, S.; Li, H.B. Spices for prevention and treatment of cancers. Nutrients 2016, 8, 495. [CrossRef] [PubMed]

32. De Camargo, A.C.; Bismara Regitano-d'Arce, M.A.; Telles Biasoto, A.C.; Shahidi, F. Enzyme-assisted extraction of phenolics from winemaking by-products: Antioxidant potential and inhibition of $\alpha$-glucosidase and lipase activities. Food Chem. 2016, 212, 395-402. [CrossRef] [PubMed]

33. Belwal, T.; Dhyani, P.; Bhatt, I.D.; Rawal, R.S.; Pande, V. Optimization extraction conditions for improving phenolic content and antioxidant activity in Berberis asiatica fruits using response surface methodology (RSM). Food Chem. 2016, 207, 115-124. [CrossRef] [PubMed] 
34. Sharmila, G.; Nikitha, V.S.; Ilaiyarasi, S.; Dhivya, K.; Rajasekar, V.; Kumar, A.N.M.; Muthukumaran, K.; Muthukumaran, C. Ultrasound assisted extraction of total phenolics from Cassia auriculata leaves and evaluation of its antioxidant activities. Ind. Crop. Prod. 2016, 84, 13-21. [CrossRef]

35. Van Tang, N.; Hong, N.T.P.; Bowyer, M.C.; van Altena, I.A.; Scarlett, C.J. Influence of solvents and novel extraction methods on bioactive compounds and antioxidant capacity of Phyllanthus amarus. Chem. Pap. 2016, 70, 556-566.

36. Strati, I.F.; Oreopoulou, V. Effect of extraction parameters on the carotenoid recovery from tomato waste. Int. J. Food Sci. Technol. 2011, 46, 23-29. [CrossRef]

37. Ho, K.K.H.Y.; Ferruzzi, M.G.; Liceaga, A.M.; Martin-Gonzalez, M.F.S. Microwave-assisted extraction of lycopene in tomato peels: Effect of extraction conditions on all-trans and cis-isomer yields. LWT-Food Sci. Technol. 2015, 62, 160-168. [CrossRef]

38. Faidi, K.; Baaka, N.; Hammami, S.; El Mokni, R.; Mighri, Z.; Mhenni, M.F. Extraction of carotenoids from Lycium ferocissimum fruits for cotton dyeing: Optimization survey based on a central composite design method. Fibers Polym. 2016, 17, 36-43. [CrossRef]

39. Azmir, J.; Zaidul, I.S.M.; Rahman, M.M.; Sharif, K.M.; Mohamed, A.; Sahena, F.; Jahurul, M.H.A.; Ghafoor, K.; Norulaini, N.A.N.; Omar, A.K.M. Techniques for extraction of bioactive compounds from plant materials: A review. J. Food Eng. 2013, 117, 426-436. [CrossRef]

40. Barba, F.J.; Zhu, Z.; Koubaa, M.; Sant'Ana, A.S.; Orlien, V. Green alternative methods for the extraction of antioxidant bioactive compounds from winery wastes and by-products: A review. Trends Food Sci. Technol. 2016, 49, 96-109. [CrossRef]

41. Xu, D.P.; Zhou, Y.; Zheng, J.; Li, S.; Li, A.N.; Li, H.B. Optimization of ultrasound-assisted extraction of natural antioxidants from the flower of Jatropha integerrima by response surface methodology. Molecules 2016, 21, 18. [CrossRef] [PubMed]

42. He, B.; Zhang, L.L.; Yue, X.Y.; Liang, J.; Jiang, J.; Gao, X.L.; Yue, P.X. Optimization of ultrasound-assisted extraction of phenolic compounds and anthocyanins from blueberry (Vaccinium ashei) wine pomace. Food Chem. 2016, 204, 70-76. [CrossRef] [PubMed]

43. Li, A.N.; Li, S.; Xu, D.P.; Xu, X.R.; Chen, Y.M.; Ling, W.H.; Chen, F.; Li, H.B. Optimization of ultrasound-assisted extraction of lycopene from papaya processing waste by response surface methodology. Food Anal. Meth. 2015, 8, 1207-1214. [CrossRef]

44. Li, Y.; Fabiano-Tixier, A.S.; Tomao, V.; Cravotto, G.; Chemat, F. Green ultrasound-assisted extraction of carotenoids based on the bio-refinery concept using sunflower oil as an alternative solvent. Ultrason. Sonochem. 2013, 20, 12-18. [CrossRef] [PubMed]

45. Milutinovic, M.; Radovanovic, N.; Corovic, M.; Siler-Marinkovic, S.; Rajilic-Stojanovic, M.; Dimitrijevic-Brankovic, S. Optimisation of microwave-assisted extraction parameters for antioxidants from waste Achillea millefolium dust. Ind. Crop. Prod. 2015, 77, 333-341. [CrossRef]

46. Bouras, M.; Chadni, M.; Barba, F.J.; Grimi, N.; Bals, O.; Vorobiev, E. Optimization of microwave-assisted extraction of polyphenols from Quercus bark. Ind. Crop. Prod. 2015, 77, 590-601. [CrossRef]

47. Tomaz, I.; Maslov, L.; Stupic, D.; Preiner, D.; Asperger, D.; Kontic, J.K. Recovery of flavonoids from grape skins by enzyme-assisted extraction. Sep. Sci. Technol. 2016, 51, 255-268. [CrossRef]

48. Ranveer, R.C.; Patil, S.N.; Sahoo, A.K. Effect of different parameters on enzyme-assisted extraction of lycopene from tomato processing waste. Food Bioprod. Process. 2013, 91, 370-375. [CrossRef]

49. Kamali, H.; Khodaverdi, E.; Hadizadeh, F.; Ghaziaskar, S.H. Optimization of phenolic and flavonoid content and antioxidants capacity of pressurized liquid extraction from Dracocephalum kotschyi via circumscribed central composite. J. Supercrit. Fluids 2016, 107, 307-314. [CrossRef]

50. Golmakani, E.; Mohammadi, A.; Sani, T.A.; Kamali, H. Phenolic and flavonoid content and antioxidants capacity of pressurized liquid extraction and perculation method from roots of Scutellaria pinnatifida a. Hamilt. Subsp alpina (Bornm) Rech. F. J. Supercrit. Fluids 2014, 95, 318-324. [CrossRef]

51. Shang, Y.F.; Kim, S.M.; Um, B. Optimisation of pressurised liquid extraction of antioxidants from black bamboo leaves. Food Chem. 2014, 154, 164-170. [CrossRef] [PubMed]

52. Sanagi, M.M.; See, H.H.; Ibrahim, W.; Abu Naim, A. Determination of carotene, tocopherols and tocotrienols in residue oil from palm pressed fiber using pressurized liquid extraction-normal phase liquid chromatography. Anal. Chim. Acta 2005, 538, 71-76. [CrossRef] 
53. Pereira, P.; Cebola, M.J.; Oliveira, M.C.; Bernardo-Gil, M.G. Supercritical fluid extraction vs. conventional extraction of myrtle leaves and berries: Comparison of antioxidant activity and identification of bioactive compounds. J. Supercrit. Fluids 2016, 113, 1-9. [CrossRef]

54. Kazan, A.; Koyu, H.; Turu, I.C.; Yesil-Celiktas, O. Supercritical fluid extraction of Prunus persica leaves and utilization possibilities as a source of phenolic compounds. J. Supercrit. Fluids 2014, 92, 55-59. [CrossRef]

55. Jimenez-Aguilar, D.M.; Escobedo-Avellaneda, Z.; Martin-Belloso, O.; Gutierrez-Uribe, J.; Valdez-Fragoso, A.; Garcia-Garcia, R.; Torres, J.A.; Welti-Chanes, J. Effect of high hydrostatic pressure on the content of phytochemical compounds and antioxidant activity of prickly pears (Opuntia ficus-indica) beverages. Food Eng. Rev. 2015, 7, 198-208. [CrossRef]

56. Lee, D.; Ghafoor, K.; Moon, S.; Kim, S.H.; Kim, S.; Chun, H.; Park, J. Phenolic compounds and antioxidant properties of high hydrostatic pressure and conventionally treated ginseng (Panax ginseng) products. Qual. Assur. Saf. Crops Foods 2015, 7, 493-500. [CrossRef]

57. Teh, S.; Niven, B.E.; Bekhit, A.E.A.; Carne, A.; Birch, E.J. Microwave and pulsed electric field assisted extractions of polyphenols from defatted canola seed cake. Int. J. Food Sci. Technol. 2015, 50, 1109-1115. [CrossRef]

58. Segovia, F.J.; Luengo, E.; Corral-Perez, J.J.; Raso, J.; Pilar Almajano, M. Improvements in the aqueous extraction of polyphenols from borage (Borago officinalis L.) leaves by pulsed electric fields: Pulsed electric fields (PEF) applications. Ind. Crop. Prod. 2015, 65, 390-396. [CrossRef]

59. Luengo, E.; Alvarez, I.; Raso, J. Improving the pressing extraction of polyphenols of orange peel by pulsed electric fields. Innov. Food Sci. Emerg. Technol. 2013, 17, 79-84. [CrossRef]

60. Rosello-Soto, E.; Barba, F.J.; Parniakov, O.; Galanakis, C.M.; Lebovka, N.; Grimi, N.; Vorobiev, E. High voltage electrical discharges, pulsed electric field, and ultrasound assisted extraction of protein and phenolic compounds from olive kernel. Food Bioprocess Technol. 2015, 8, 885-894. [CrossRef]

61. Esclapez, M.D.; Garcia-Perez, J.V.; Mulet, A.; Carcel, J.A. Ultrasound-assisted extraction of natural products. Food Eng. Rev. 2011, 3, 108-120. [CrossRef]

62. Soria, A.C.; Villamiel, M. Effect of ultrasound on the technological properties and bioactivity of food: A review. Trends Food Sci. Technol. 2010, 21, 323-331. [CrossRef]

63. Chemat, F.; Zill-e-Huma; Khan, M.K. Applications of ultrasound in food technology: Processing, preservation and extraction. Ultrason. Sonochem. 2011, 18, 813-835. [CrossRef] [PubMed]

64. Talmaciu, A.I.; Volf, I.; Popa, V.I. A comparative analysis of the "green" techniques applied for polyphenols extraction from bioresources. Chem. Biodivers. 2015, 12, 1635-1651. [CrossRef] [PubMed]

65. Espada-Bellido, E.; Ferreiro-Gonzalez, M.; Carrera, C.; Palma, M.; Barroso, C.G.; Barbero, G.F. Optimization of the ultrasound-assisted extraction of anthocyanins and total phenolic compounds in mulberry (Morus nigra) pulp. Food Chem. 2017, 219, 23-32. [CrossRef] [PubMed]

66. Virot, M.; Tomao, V.; Le Bourvellec, C.; Renard, C.M.C.G.; Chemat, F. Towards the industrial production of antioxidants from food processing by-products with ultrasound-assisted extraction. Ultrason. Sonochem. 2010, 17, 1066-1074. [CrossRef] [PubMed]

67. Liu, C.T.; Wu, C.Y.; Weng, Y.M.; Tseng, C.Y. Ultrasound-assisted extraction methodology as a tool to improve the antioxidant properties of herbal drug Xiao-chia-hu-tang. J. Ethnopharmacol. 2005, 99, 293-300. [CrossRef] [PubMed]

68. Kazemi, M.; Karim, R.; Mirhosseini, H.; Hamid, A.A. Optimization of pulsed ultrasound-assisted technique for extraction of phenolics from pomegranate peel of Malas variety: Punicalagin and hydroxybenzoic acids. Food Chem. 2016, 206, 156-166. [CrossRef] [PubMed]

69. Pan, Z.; Qu, W.; Ma, H.; Atungulu, G.G.; McHugh, T.H. Continuous and pulsed ultrasound-assisted extractions of antioxidants from pomegranate peel. Ultrason. Sonochem. 2011, 18, 1249-1257. [CrossRef] [PubMed]

70. Xu, W.J.; Zhai, J.W.; Cui, Q.; Liu, J.Z.; Luo, M.; Fu, Y.J.; Zu, Y.G. Ultra-turrax based ultrasound-assisted extraction of five organic acids from honeysuckle (Lonicera japonica Thunb.) and optimization of extraction process. Sep. Purif. Technol. 2016, 166, 73-82. [CrossRef]

71. Tan, Z.J.; Yi, Y.J.; Wang, H.Y.; Zhou, W.L.; Wang, C.Y. Extraction, preconcentration and isolation of flavonoids from Apocynum venetum L. Leaves using ionic liquid-based ultrasonic-assisted extraction coupled with an aqueous biphasic system. Molecules 2016, 21, 262. [CrossRef] [PubMed]

72. Zhang, H.F.; Yang, X.H.; Wang, Y. Microwave assisted extraction of secondary metabolites from plants: Current status and future directions. Trends Food Sci. Technol. 2011, 22, 672-688. [CrossRef] 
73. Florez, N.; Conde, E.; Dominguez, H. Microwave assisted water extraction of plant compounds. J. Chem. Technol. Biotechnol. 2015, 90, 590-607. [CrossRef]

74. Pap, N.; Beszedes, S.; Pongracz, E.; Myllykoski, L.; Gabor, M.; Gyimes, E.; Hodur, C.; Keiski, R.L. Microwave-assisted extraction of anthocyanins from black currant marc. Food Bioprocess Technol. 2013, 6, 2666-2674. [CrossRef]

75. Dahmoune, F.; Spigno, G.; Moussi, K.; Remini, H.; Cherbal, A.; Madani, K. Pistacia lentiscus leaves as a source of phenolic compounds: Microwave-assisted extraction optimized and compared with ultrasound-assisted and conventional solvent extraction. Ind. Crop. Prod. 2014, 61, 31-40. [CrossRef]

76. Dahmoune, F.; Nayak, B.; Moussi, K.; Remini, H.; Madani, K. Optimization of microwave-assisted extraction of polyphenols from Myrtus communis L. Leaves. Food Chem. 2015, 166, 585-595. [CrossRef] [PubMed]

77. Tatke, P.; Jaiswal, Y. An overview of microwave assisted extraction and its applications in herbal drug research. Res. J. Med. Plant 2011, 5, 21-31. [CrossRef]

78. Pasrija, D.; Anandharamakrishnan, C. Techniques for extraction of green tea polyphenols: A review. Food Bioprocess Technol. 2015, 8, 935-950. [CrossRef]

79. Routray, W.; Orsat, V. Microwave-assisted extraction of flavonoids: A review. Food Bioprocess Technol. 2012, 5, 409-424. [CrossRef]

80. Li, Y.; Fabiano-Tixier, A.S.; Vian, M.A.; Chemat, F. Solvent-free microwave extraction of bioactive compounds provides a tool for green analytical chemistry. TrAC-Trends Anal. Chem. 2013, 47, 1-11. [CrossRef]

81. Wang, Z.M.; Ding, L.; Li, T.C.; Zhou, X.; Wang, L.; Zhang, H.Q.; Liu, L.; Li, Y.; Liu, Z.H.; Wang, H.J.; et al. Improved solvent-free microwave extraction of essential oil from dried Cuminum cyminum L. and Zanthoxylum bungeanum Maxim. J. Chromatogr. A 2006, 1102, 11-17. [CrossRef] [PubMed]

82. Sahin, S. A novel technology for extraction of phenolic antioxidants from mandarin (Citrus deliciosa Tenore) leaves: Solvent-free microwave extraction. Korean J. Chem. Eng. 2015, 32, 950-957. [CrossRef]

83. Bendjersi, F.Z.; Tazerouti, F.; Belkhelfa-Slimani, R.; Djerdjouri, B.; Meklati, B.Y. Phytochemical composition of the Algerian Laurus nobilis L. Leaves extracts obtained by solvent-free microwave extraction and investigation of their antioxidant activity. J. Essent. Oil Res. 2016, 28, 202-210. [CrossRef]

84. Zill-e-Huma, M.A.V.; Maingonnat, J.F.; Chemat, F. Clean recovery of antioxidant flavonoids from onions: Optimising solvent free microwave extraction method. J. Chromatogr. A 2009, 1216, 7700-7707. [CrossRef] [PubMed]

85. Perino-Issartier, S.; Zill-e-Huma; Abert-Vian, M.; Chemat, F. Solvent free microwave-assisted extraction of antioxidants from sea buckthorn (Hippophae rhamnoides) food by-products. Food Bioprocess Technol. 2011, 4, 1020-1028. [CrossRef]

86. Michel, T.; Destandau, E.; Elfakir, C. Evaluation of a simple and promising method for extraction of antioxidants from sea buckthorn (Hippophae rhamnoides L.) berries: Pressurised solvent-free microwave assisted extraction. Food Chem. 2011, 126, 1380-1386. [CrossRef]

87. Gu, H.; Chen, F.; Zhang, Q.; Zang, J. Application of ionic liquids in vacuum microwave-assisted extraction followed by macroporous resin isolation of three flavonoids rutin, hyperoside and hesperidin from Sorbus tianschanica leaves. J. Chromatogr. B Anal. Technol. Biomed. Life Sci. 2016, 1014, 45-55. [CrossRef] [PubMed]

88. Cheng, X.; Bi, L.W.; Zhao, Z.D.; Chen, Y.X. Advances in enzyme assisted extraction of natural products. In AER-Advances in Engineering Research, 3nd ed.; Yarlagadda, P., Ed.; Atlantis Press: Paris, France, 2015; Volume 27, pp. 371-375.

89. Liu, X.; Hu, Y.; Wei, D. Optimization of enzyme-based ultrasonic/microwave-assisted extraction and evaluation of antioxidant activity of orcinol glucoside from the rhizomes of Curculigo orchioides Gaertn. Med. Chem. Res. 2014, 23, 2360-2367. [CrossRef]

90. Dinkova, R.; Heffels, P.; Shikov, V.; Weber, F.; Schieber, A.; Mihalev, K. Effect of enzyme-assisted extraction on the chilled storage stability of bilberry (Vaccinium myrtillus L.) anthocyanins in skin extracts and freshly pressed juices. Food Res. Int. 2014, 65, 35-41. [CrossRef]

91. Nguyen, T.H.; Smagghe, G.; Gonzales, G.B.; van Camp, J.; Raes, K. Enzyme-assisted extraction enhancing the phenolic release from cauliflower (Brassica oleracea L. Var. Botrytis) outer Leaves. J. Agric. Food Chem. 2014, 62, 7468-7476.

92. Mushtaq, M.; Sultana, B.; Bhatti, H.N.; Asghar, M. RSM based optimized enzyme-assisted extraction of antioxidant phenolics from underutilized watermelon (Citrullus lanatus Thunb.) rind. J. Food Sci. Technol.-Mysore 2015, 52, 5048-5056. [CrossRef] [PubMed] 
93. Liu, J.J.; Gasmalla, M.A.A.; Li, P.; Yang, R. Enzyme-assisted extraction processing from oilseeds: Principle, processing and application. Innov. Food Sci. Emerg. Technol. 2016, 35, 184-193. [CrossRef]

94. Puri, M.; Sharma, D.; Barrow, C.J. Enzyme-assisted extraction of bioactives from plants. Trends Biotechnol. 2012, 30, 37-44. [CrossRef] [PubMed]

95. Park, C.; Kim, S.; Lee, D.; Park, D.J.; Imm, J. Enzyme and high pressure assisted extraction of tricin from rice hull and biological activities of rice hull extract. Food Sci. Biotechnol. 2016, 25, 159-164. [CrossRef]

96. Mustafa, A.; Turner, C. Pressurized liquid extraction as a green approach in food and herbal plants extraction: A review. Anal. Chim. Acta 2011, 703, 8-18. [CrossRef] [PubMed]

97. Herrero, M.; del Pilar Sanchez-Camargo, A.; Cifuentes, A.; Ibanez, E. Plants, seaweeds, microalgae and food by-products as natural sources of functional ingredients obtained using pressurized liquid extraction and supercritical fluid extraction. TrAC-Trends Anal. Chem. 2015, 71, 26-38. [CrossRef]

98. Setyaningsih, W.; Saputro, I.E.; Palma, M.; Barroso, C.G. Pressurized liquid extraction of phenolic compounds from rice (Oryza sativa) grains. Food Chem. 2016, 192, 452-459. [CrossRef] [PubMed]

99. Breithaupt, D.E. Simultaneous HPLC determination of carotenoids used as food coloring additives: Applicability of accelerated solvent extraction. Food Chem. 2004, 86, 449-456. [CrossRef]

100. Bozan, B.; Altinay, R.C. Accelerated solvent extraction of flavan-3-ol derivatives from grape seeds. Food Sci. Technol. Res. 2014, 20, 409-414. [CrossRef]

101. Cai, Z.; Qu, Z.; Lan, Y.; Zhao, S.; Ma, X.; Wan, Q.; Jing, P.; Li, P. Conventional, ultrasound-assisted, and accelerated-solvent extractions of anthocyanins from purple sweet potatoes. Food Chem. 2016, 197, $266-272$. [CrossRef] [PubMed]

102. Nieto, A.; Borrull, F.; Pocurull, E.; Marce, R.M. Pressurized liquid extraction: A useful technique to extract pharmaceuticals and personal-care products from sewage sludge. TrAC Trends Anal. Chem. 2010, 29, 752-764. [CrossRef]

103. Franquin-Trinquier, S.; Maury, C.; Baron, A.; Le Meurlay, D.; Mehinagic, E. Optimization of the extraction of apple monomeric phenolics based on response surface methodology: Comparison of pressurized liquid-solid extraction and manual-liquid extraction. J. Food Compos. Anal. 2014, 34, 56-67. [CrossRef]

104. Pineiro, Z.; Palma, M.; Barroso, C.G. Determination of trans-resveratrol in grapes by pressurised liquid extraction and fast high-performance liquid chromatography. J. Chromatogr. A 2006, 1110, 61-65. [CrossRef] [PubMed]

105. Wianowska, D.; Typek, R.; Dawidowicz, A.L. Chlorogenic acid stability in pressurized liquid extraction conditions. J. AOAC Int. 2015, 98, 415-421. [CrossRef] [PubMed]

106. Yen, H.; Yang, S.; Chen, C.; Jesisca; Chang, J. Supercritical fluid extraction of valuable compounds from microalgal biomass. Bioresour. Technol. 2015, 184, 291-296. [CrossRef] [PubMed]

107. Radzali, S.A.; Baharin, B.S.; Othman, R.; Markom, M.; Rahman, R.A. Co-solvent selection for supercritical fluid extraction of astaxanthin and other carotenoids from Penaeus monodon Waste. J. Oleo Sci. 2014, 63, 769-777. [CrossRef] [PubMed]

108. Capuzzo, A.; Maffei, M.E.; Occhipinti, A. Supercritical fluid extraction of plant flavors and fragrances. Molecules 2013, 18, 7194-7238. [CrossRef] [PubMed]

109. Da Silva, R.P.F.F.; Rocha-Santos, T.A.P.; Duarte, A.C. Supercritical fluid extraction of bioactive compounds. TrAC-Trends Anal. Chem. 2016, 76, 40-51. [CrossRef]

110. Sharif, K.M.; Rahman, M.M.; Azmir, J.; Mohamed, A.; Jahurul, M.H.A.; Sahena, F.; Zaidul, I.S.M. Experimental design of supercritical fluid extraction-A review. J. Food Eng. 2014, 124, 105-116. [CrossRef]

111. Konar, N.; Dalabasmaz, S.; Poyrazoglu, E.S.; Artik, N.; Colak, A. The determination of the caffeic acid derivatives of Echinacea purpurea aerial parts under various extraction conditions by supercritical fluid extraction (SFE). J. Supercrit. Fluids 2014, 89, 128-136. [CrossRef]

112. Maran, J.P.; Priya, B.; Manikandan, S. Modeling and optimization of supercritical fluid extraction of anthocyanin and phenolic compounds from Syzygium cumini fruit pulp. J. Food Sci. Technol. Mysore 2014, 51, 1938-1946. [CrossRef] [PubMed]

113. Da Silva, G.F.; Konat Gandolfi, P.H.; Almeida, R.N.; Lucas, A.M.; Cassel, E.; Figueiro Vargas, R.M. Analysis of supercritical fluid extraction of lycopodine using response surface methodology and process mathematical modeling. Chem. Eng. Res. Des. 2015, 100, 353-361. [CrossRef] 
114. Haghayegh, M.; Zabihi, F.; Eikani, M.H.; Moghadas, B.K.; Yazdi, S.A.V. Supercritical fluid extraction of flavonoids and terpenoids from herbal compounds: Experiments and mathematical modeling. J. Essent. Oil Bear. Plants. 2015, 18, 1253-1265. [CrossRef]

115. Zaghdoudi, K.; Framboisier, X.; Frochot, C.; Vanderesse, R.; Barth, D.; Kalthoum-Cherif, J.; Blanchard, F.; Guiavarc'h, Y. Response surface methodology applied to supercritical fluid extraction (SFE) of carotenoids from Persimmon (Diospyros kaki L.). Food Chem. 2016, 208, 209-219. [CrossRef] [PubMed]

116. Liu, X.; Yang, D.; Liu, J.; Xu, K.; Wu, G. Modeling of supercritical fluid extraction of flavonoids from Calycopteris floribunda leaves. Chem. Pap. 2014, 68, 316-323. [CrossRef]

117. Talmaciu, A.I.; Volf, I.; Popa, V.I. Supercritical fluids and ultrasound assisted extractions applied to spruce bark conversion. Environ. Eng. Manag. J. 2015, 14, 615-623.

118. Solana, M.; Mirofci, S.; Bertucco, A. Production of phenolic and glucosinolate extracts from rocket salad by supercritical fluid extraction: Process design and cost benefits analysis. J. Food Eng. 2016, 168, 35-41. [CrossRef]

119. Pasquel Reategui, J.L.; Da Fonseca Machado, A.P.; Barbero, G.F.; Rezende, C.A.; Martinez, J. Extraction of antioxidant compounds from blackberry (Rubus sp.) bagasse using supercritical $\mathrm{CO}_{2}$ assisted by ultrasound. J. Supercrit. Fluids 2014, 94, 223-233. [CrossRef]

120. Mushtaq, M.; Sultana, B.; Anwar, F.; Adnan, A.; Rizvi, S.S.H. Enzyme-assisted supercritical fluid extraction of phenolic antioxidants from pomegranate peel. J. Supercrit. Fluids 2015, 104, 122-131. [CrossRef]

121. Corrales, M.; Garcia, A.F.; Butz, P.; Tauscher, B. Extraction of anthocyanins from grape skins assisted by high hydrostatic pressure. J. Food Eng. 2009, 90, 415-421. [CrossRef]

122. Altuner, E.M.; Tokusoglu, O. The effect of high hydrostatic pressure processing on the extraction, retention and stability of anthocyanins and flavonols contents of berry fruits and berry juices. Int. J. Food Sci. Technol. 2013, 48, 1991-1997. [CrossRef]

123. Toepfl, S.; Mathys, A.; Heinz, V.; Knorr, D. Review: Potential of high hydrostatic pressure and pulsed electric fields for energy efficient and environmentally friendly food processing. Food Rev. Int. 2006, 22, 405-423. [CrossRef]

124. Xi, J.; Shen, D.; Zhao, S.; Lu, B.; Li, Y.; Zhang, R. Characterization of polyphenols from green tea leaves using a high hydrostatic pressure extraction. Int. J. Pharm. 2009, 382, 139-143. [CrossRef] [PubMed]

125. Uzelac, V.D.; Putnik, P.; Zoric, Z.; Jezek, D.; Karlovic, S.; Kovacevic, D.B. Winery by-products: Anthocyanins recovery from red grape skin by high hydrostatic pressure extraction (HHPE). Ann. Nutr. Metab. 2015, 671, 522-523.

126. Kovacevic, D.B.; Putnik, P.; Pedisic, S.; Jazek, D.; Karlovic, S.; Uzelac, V.D. High hydrostatic pressure extraction of flavonoids from freeze-dried red grape skin as winemaking by-product. Ann. Nutr. Metab. $2015,671,521-522$.

127. Xi, J.; Luo, S. The mechanism for enhancing, extraction of ferulic acid from Radix Angelica sinensis by high hydrostatic pressure. Sep. Purif. Technol. 2016, 165, 208-213. [CrossRef]

128. Lopez, N.; Puertolas, E.; Condon, S.; Raso, J.; Alvarez, I. Enhancement of the extraction of betanine from red beetroot by pulsed electric fields. J. Food Eng. 2009, 90, 60-66. [CrossRef]

129. Zderic, A.; Zondervan, E. Polyphenol extraction from fresh tea leaves by pulsed electric field: A study of mechanisms. Chem. Eng. Res. Des. 2016, 109, 586-592. [CrossRef]

130. Bouras, M.; Grimi, N.; Bals, O.; Vorobiev, E. Impact of pulsed electric fields on polyphenols extraction from Norway spruce bark. Ind. Crop. Prod. 2016, 80, 50-58. [CrossRef]

131. Zhou, Y.; Zhao, X.; Huang, H. Effects of pulsed electric fields on anthocyanin extraction yield of blueberry processing by-products. J. Food Process Preserv. 2015, 39, 1898-1904. [CrossRef]

132. Bansal, V.; Sharma, A.; Ghanshyam, C.; Singla, M.L. Optimization and characterization of pulsed electric field parameters for extraction of quercetin and ellagic acid in emblica officinalis juice. J. Food Meas. Charact. 2014, 8, 225-233. [CrossRef]

133. Gachovska, T.; Cassada, D.; Subbiah, J.; Hanna, M.; Thippareddi, H.; Snow, D. Enhanced anthocyanin extraction from red cabbage using pulsed electric field processing. J. Food Sci. 2010, 75, E323-E329. [CrossRef] [PubMed]

134. Luengo, E.; Martinez, J.M.; Bordetas, A.; Alvarez, I.; Raso, J. Influence of the treatment medium temperature on lutein extraction assisted by pulsed electric fields from Chlorella vulgaris. Innov. Food Sci. Emerg. Technol. 2015, 29, 15-22. [CrossRef]

135. Roohinejad, S.; Oey, I.; Everett, D.W.; Niven, B.E. Evaluating the effectiveness of beta-carotene extraction from pulsed electric field-treated carrot pomace using oil-in-water microemulsion. Food Bioprocess Technol. 2014, 7, 3336-3348. [CrossRef] 
136. Lopez, N.; Puertolas, E.; Condon, S.; Alvarez, I.; Raso, J. Effects of pulsed electric fields on the extraction of phenolic compounds during the fermentation of must of Tempranillo grapes. Innov. Food Sci. Emerg. Technol. 2008, 9, 477-482. [CrossRef]

137. Boussetta, N.; Vorobiev, E. Extraction of valuable biocompounds assisted by high voltage electrical discharges: A review. Comptes Rendus Chim. 2014, 17, 197-203. [CrossRef]

138. Boussetta, N.; Lanoiselle, J.; Bedel-Cloutour, C.; Vorobiev, E. Extraction of soluble matter from grape pomace by high voltage electrical discharges for polyphenol recovery: Effect of sulphur dioxide and thermal treatments. J. Food Eng. 2009, 95, 192-198. [CrossRef]

139. Rajha, H.N.; Boussetta, N.; Louka, N.; Maroun, R.G.; Vorobiev, E. Electrical, mechanical, and chemical effects of high-voltage electrical discharges on the polyphenol extraction from vine shoots. Innov. Food Sci. Emerg. Technol. 2015, 31, 60-66. [CrossRef]

140. Sarkis, J.R.; Boussetta, N.; Tessaro, I.C.; Ferreira Marczak, L.D.; Vorobiev, E. Application of pulsed electric fields and high voltage electrical discharges for oil extraction from sesame seeds. J. Food Eng. 2015, 153, 20-27. [CrossRef]

141. Le, H.V.; Le, V.V.M. Comparison of enzyme-assisted and ultrasound-assisted extraction of vitamin C and phenolic compounds from acerola (Malpighia emarginata DC.) fruit. Int. J. Food Sci. Technol. 2012, 47, 1206-1214. [CrossRef]

142. Rodriguez-Perez, C.; Gilbert-Lopez, B.; Mendiola, J.A.; Quirantes-Pine, R.; Segura-Carretero, A.; Ibanez, E. Optimization of microwave-assisted extraction and pressurized liquid extraction of phenolic compounds from Moringa oleifera leaves by multiresponse surface methodology. Electrophoresis 2016, 37, 1938-1946. [CrossRef] [PubMed]

143. Das, A.K.; Mandal, V.; Mandal, S.C. A brief understanding of process optimisation in microwave-assisted extraction of botanical materials: Options and opportunities with chemometric tools. Phytochem. Anal. 2014, 25, 1-12. [CrossRef] [PubMed]

144. Chemat, F.; Rombaut, N.; Sicaire, A.G.; Meullemiestre, A.; Fabiano-Tixier, A.S.; Abert-Vian, M. Ultrasound assisted extraction of food and natural products. Mechanisms, techniques, combinations, protocols and applications. A review. Ultrason. Sonochem. 2017, 34, 540-560. [CrossRef] [PubMed]

145. Eskilsson, C.S.; Bjorklund, E. Analytical-scale microwave-assisted extraction. J. Chromatogr. A 2000, 902, 227-250. [CrossRef]

146. Senorans, F.J.; Ibanez, E.; Cifuentes, A. New trends in food processing. Crit. Rev. Food Sci. Nutr. 2003, 43, 507-526. [CrossRef] [PubMed]

147. Parniakov, O.; Barba, F.J.; Grimi, N.; Lebovka, N.; Vorobiev, E. Impact of pulsed electric fields and high voltage electrical discharges on extraction of high-added value compounds from papaya peels. Food Res. Int. 2014, 65, 337-343. [CrossRef]

148. Huang, D.J.; Ou, B.X.; Prior, R.L. The chemistry behind antioxidant capacity assays. J. Agric. Food Chem. 2005, 53, 1841-1856. [CrossRef] [PubMed]

149. Prior, R.L.; Wu, X.L.; Schaich, K. Standardized methods for the determination of antioxidant capacity and phenolics in foods and dietary supplements. J. Agric. Food Chem. 2005, 53, 4290-4302. [CrossRef] [PubMed]

150. Lopez-Alarcon, C.; Denicola, A. Evaluating the antioxidant capacity of natural products: A review on chemical and cellular-based assays. Anal. Chim. Acta 2013, 763, 1-10. [CrossRef] [PubMed]

151. Frankel, E.N.; Meyer, A.S. The problems of using one-dimensional methods to evaluate multifunctional food and biological antioxidants. J. Sci. Food Agric. 2000, 80, 1925-1941. [CrossRef]

152. Arts, M.; Dallinga, J.S.; Voss, H.P.; Haenen, G.; Bast, A. A new approach to assess the total antioxidant capacity using the TEAC assay. Food Chem. 2004, 88, 567-570. [CrossRef]

153. Schaich, K.M.; Tian, X.; Xie, J. Hurdles and pitfalls in measuring antioxidant efficacy: A critical evaluation of ABTS, DPPH, and ORAC assays (Reprinted). J. Funct. Food. 2015, 18, 782-796. [CrossRef]

154. Awika, J.M.; Rooney, L.W.; Wu, X.L.; Prior, R.L.; Cisneros-Zevallos, L. Screening methods to measure antioxidant activity of sorghum (Sorghum bicolor) and sorghum products. J. Agric. Food Chem. 2003, 51, 6657-6662. [CrossRef] [PubMed]

155. Antolovich, M.; Prenzler, P.D.; Patsalides, E.; McDonald, S.; Robards, K. Methods for testing antioxidant activity. Analyst 2002, 127, 183-198. [CrossRef] [PubMed]

156. Pulido, R.; Bravo, L.; Saura-Calixto, F. Antioxidant activity of dietary polyphenols as determined by a modified ferric reducing/antioxidant power assay. J. Agric. Food Chem. 2000, 48, 3396-3402. [CrossRef] [PubMed] 
157. Ou, B.X.; Huang, D.J.; Hampsch-Woodill, M.; Flanagan, J.A.; Deemer, E.K. Analysis of antioxidant activities of common vegetables employing oxygen radical absorbance capacity (ORAC) and ferric reducing antioxidant power (FRAP) assays: A comparative study. J. Agric. Food Chem. 2002, 50, 3122-3128. [CrossRef] [PubMed]

158. Benzie, I.F.F.; Strain, J.J. The ferric reducing ability of plasma (FRAP) as a measure of "Antioxidant power": The FRAP assay. Anal. Biochem. 1996, 239, 70-76. [CrossRef] [PubMed]

159. Amorati, R.; Valgimigli, L. Advantages and limitations of common testing methods for antioxidants. Free Radic. Res. 2015, 49, 633-649. [CrossRef] [PubMed]

160. Ozyurek, M.; Guclu, K.; Apak, R. The main and modified CUPRAC methods of antioxidant measurement. TrAC-Trends Anal. Chem. 2011, 30, 652-664. [CrossRef]

161. Apak, R.; Guclu, K.; Demirata, B.; Ozyurek, M.; Celik, S.E.; Bektasoglu, B.; Berker, K.I.; Ozyurt, D. Comparative evaluation of various total antioxidant capacity assays applied to phenolic compounds with the CUPRAC assay. Molecules 2007, 12, 1496-1547. [CrossRef] [PubMed]

162. Gulcin, I. Antioxidant activity of food constituents: An overview. Arch. Toxicol. 2012, 86, 345-391. [CrossRef] [PubMed]

163. Singleton, V.L.; Orthofer, R.; Lamuela-Raventos, R.M. Analysis of total phenols and other oxidation substrates and antioxidants by means of Folin-Ciocalteu reagent. In Methods in Enzymology; Packer, L., Ed.; Elsevier Academic Press: Sandiego, Chile, 1999; Volume 299, pp. 152-178.

164. Cicco, N.; Lanorte, M.T.; Paraggio, M.; Viggiano, M.; Lattanzio, V. A reproducible, rapid and inexpensive Folin-Ciocalteu micro-method in determining phenolics of plant methanol extracts. Microchem. J. 2009, 91, 107-110. [CrossRef]

165. Magalhaes, L.M.; Segundo, M.A.; Reis, S.; Lima, J.L.F.C.; Toth, I.V.; Rangel, A.O.S.S. Automatic flow system for sequential determination of ABTS(center dot+) scavenging capacity and Folin-Ciocalteu index: A comparative study in food products. Anal. Chim. Acta 2007, 592, 193-201. [CrossRef] [PubMed]

166. Shaghaghia, M.; Manzoori, J.L.; Jouyban, A. Determination of total phenols in tea infusions, tomato and apple juice by terbium sensitized fluorescence method as an alternative approach to the Folin-Ciocalteu spectrophotometric method. Food Chem. 2008, 108, 695-701. [CrossRef] [PubMed]

167. Wootton-Beard, P.C.; Moran, A.; Ryan, L. Stability of the total antioxidant capacity and total polyphenol content of 23 commercially available vegetable juices before and after in vitro digestion measured by FRAP, DPPH, ABTS and Folin-Ciocalteu methods. Food Res. Int. 2011, 44, 217-224. [CrossRef]

168. Yoo, K.S.; Lee, E.J.; Leskovar, D.; Patil, B.S. Development of an automated method for Folin-Ciocalteu total phenolic assay in artichoke extracts. J. Food Sci. 2012, 77, C1278-C1283. [CrossRef] [PubMed]

169. Everette, J.D.; Bryant, Q.M.; Green, A.M.; Abbey, Y.A.; Wangila, G.W.; Walker, R.B. Thorough study of reactivity of various compound classes toward the Folin-Ciocalteu reagent. J. Agric. Food Chem. 2010, 58, 8139-8144. [CrossRef] [PubMed]

170. Berker, K.I.; Olgun, F.A.O.; Ozyurt, D.; Demirata, B.; Apak, R. Modified Folin-Ciocalteu antioxidant capacity assay for measuring lipophilic antioxidants. J. Agric. Food Chem. 2013, 61, 4783-4791. [CrossRef] [PubMed]

171. Sanchez-Moreno, C. Review: Methods used to evaluate the free radical scavenging activity in foods and biological systems. Food Sci. Technol. Int. 2002, 8, 121-137. [CrossRef]

172. Nkhili, E.; Brat, P. Reexamination of the ORAC assay: Effect of metal ions. Anal. Bioanal. Chem. 2011, 400, 1451-1458. [CrossRef] [PubMed]

173. Ou, B.X.; Hampsch-Woodill, M.; Prior, R.L. Development and validation of an improved oxygen radical absorbance capacity assay using fluorescein as the fluorescent probe. J. Agric. Food Chem. 2001, 49, 4619-4626. [CrossRef] [PubMed]

174. Wood, L.G.; Gibson, P.G.; Garg, M.L. A review of the methodology for assessing in vivo antioxidant capacity. J. Sci. Food Agric. 2006, 86, 2057-2066. [CrossRef]

175. Wolfe, K.L.; Liu, R.H. Cellular antioxidant activity (CAA) assay for assessing antioxidants, foods, and dietary supplements. J. Agric. Food Chem. 2007, 55, 8896-8907. [CrossRef] [PubMed]

176. Xing, J.; Wang, G.; Zhang, Q.; Liu, X.; Yin, B.; Fang, D.; Zhao, J.; Zhang, H.; Chen, Y.Q.; Chen, W. Determining antioxidant activities of lactobacilli by cellular antioxidant assay in mammal cells. J. Funct. Food 2015, 19, 554-562. [CrossRef]

177. Blasa, M.; Angelino, D.; Gennari, L.; Ninfali, P. The cellular antioxidant activity in red blood cells (CAA-RBC): A new approach to bioavailability and synergy of phytochemicals and botanical extracts. Food Chem. 2011, 125, 685-691. [CrossRef] 
178. Zhang, X.D.; Xu, Y.; Zhang, T.; Lu, J.J. Assessing plant antioxidants by cellular antioxidant activity assay based on microfluidic cell chip with arrayed microchannels. Chin. J. Anal. Chem. 2016, 44, 604-609. [CrossRef]

179. O'sullivan, A.M.; O'Callaghan, Y.C.; O'Grady, M.N.; Queguineur, B.; Hanniffy, D.; Troy, D.J.; Kerry, J.P.; O'Brien, N.M. In vitro and cellular antioxidant activities of seaweed extracts prepared from five brown seaweeds harvested in spring from the west coast of Ireland. Food Chem. 2011, 126, 1064-1070. [CrossRef]

180. Baroni, M.V.; Di Paola Naranjo, R.D.; Garcia-Ferreyra, C.; Otaiza, S.; Wunderlin, D.A. How good antioxidant is the red wine? Comparison of some in vitro and in vivo methods to assess the antioxidant capacity of Argentinean red wines. LWT-Food Sci. Technol. 2012, 47, 1-7. [CrossRef]

181. Biswas, S.K.; McClure, D.; Jimenez, L.A.; Megson, I.L.; Rahman, I. Curcumin induces glutathione biosynthesis and inhibits NF- $\kappa B$ activation and interleukin- 8 release in alveolar epithelial cells: Mechanism of free radical scavenging activity. Antioxid. Redox Signal. 2005, 7, 32-41. [CrossRef] [PubMed]

182. Xie, C.; Kang, J.; Ferguson, M.E.; Nagarajan, S.; Badger, T.M.; Wu, X. Blueberries reduce pro-inflammatory cytokine TNF-alpha and IL-6 production in mouse macrophages by inhibiting NF- $\mathrm{kB}$ activation and the MAPK pathway. Mol. Nutr. Food Res. 2011, 55, 1587-1591. [CrossRef] [PubMed]

183. Song, W.; Derito, C.M.; Liu, M.K.; He, X.; Dong, M.; Liu, R.H. Cellular antioxidant activity of common vegetables. J. Agric. Food Chem. 2010, 58, 6621-6629. [CrossRef] [PubMed]

184. Wolfe, K.L.; Kang, X.; He, X.; Dong, M.; Zhang, Q.; Liu, R.H. Cellular antioxidant activity of common fruits. J. Agric. Food Chem. 2008, 56, 8418-8426. [CrossRef] [PubMed]

185. Surarit, W.; Jansom, C.; Lerdvuthisopon, N.; Kongkham, S.; Hansakul, P. Evaluation of antioxidant activities and phenolic subtype contents of ethanolic bran extracts of Thai pigmented rice varieties through chemical and cellular assays. Int. J. Food Sci. Technol. 2015, 50, 990-998. [CrossRef]

186. Erlund, I. Review of the flavonoids quercetin, hesperetin, and naringenin. Dietary sources, bioactivities, bioavailability, and epidemiology. Nutr. Res. 2004, 24, 851-874. [CrossRef]

187. Liggins, J.; Bluck, L.J.C.; Runswick, S.; Atkinson, C.; Coward, W.A.; Bingham, S.A. Daidzein and genistein contents of vegetables. Br. J. Nutr. 2000, 84, 717-725. [PubMed]

188. Mezzomo, N.; Ferreira, S.R. Carotenoids functionality, sources, and processing by supercritical technology: A review. J. Chem. 2016, 2016, 3164312. [CrossRef]

189. Borguini, R.G.; Ferraz Da Silva Torres, E.A. Tomatoes and tomato products as dietary sources of antioxidants. Food Rev. Int. 2009, 25, 313-325. [CrossRef]

190. Abdel-Aal, E.S.M.; Akhtar, H.; Zaheer, K.; Ali, R. Dietary sources of lutein and zeaxanthin carotenoids and their role in eye health. Nutrients 2013, 5, 1169-1185. [CrossRef] [PubMed]

191. Raposo, M.F.D.J.; de Morais, A.M.M.B.; de Morais, R.M.S.C. Carotenoids from marine microalgae: A valuable natural source for the prevention of chronic diseases. Mar. Drugs 2015, 13, 5128-5155. [CrossRef] [PubMed]

192. Xu, B.; Chang, S.K.C. Comparative study on antiproliferation properties and cellular antioxidant activities of commonly consumed food legumes against nine human cancer cell lines. Food Chem. 2012, 134, 1287-1296. [CrossRef] [PubMed]

193. Zhou, Q.; Lu, W.; Niu, Y.; Liu, J.; Zhang, X.; Gao, B.; Akoh, C.C.; Shi, H.; Yu, L.L. Identification and quantification of phytochemical composition and anti-inflammatory, cellular antioxidant, and radical scavenging activities of 12 plantago species. J. Agric. Food Chem. 2013, 61, 6693-6702. [CrossRef] [PubMed]

194. Lai, Q.; Wang, H.; Guo, X.; Abbasi, A.M.; Wang, T.; Li, T.; Fu, X.; Li, J.; Liu, R.H. Comparison of phytochemical profiles, antioxidant and cellular antioxidant activities of seven cultivars of Aloe. Int. J. Food Sci. Technol. 2016, 51, 1489-1494. [CrossRef]

195. Li, Y.; Sun, H.Y.; Yu, X.Y.; Liu, D.; Wan, H.X. Evaluation of cellular antioxidant and antiproliferative activities of five main Phyllanthus emblica L. cultivars in China. Indian J. Pharm. Sci. 2015, 77, 274-282. [CrossRef] [PubMed]

(c) 2017 by the authors; licensee MDPI, Basel, Switzerland. This article is an open access article distributed under the terms and conditions of the Creative Commons Attribution (CC-BY) license (http://creativecommons.org/licenses/by/4.0/). 